Article

\title{
Impact of Drying Processes on the Nutritional Composition, Volatile Profile, Phytochemical Content and Bioactivity of Salicornia ramosissima J. Woods
}

\author{
Sheila C. Oliveira-Alves ${ }^{1}$, Fábio Andrade ${ }^{1}$, Inês Prazeres ${ }^{1}$, Andreia B. Silva ${ }^{2,3} \mathbb{D}$, Jorge Capelo ${ }^{4}$, \\ Bernardo Duarte ${ }^{5,6}{ }^{(D}$, Isabel Caçador ${ }^{5,6}$, Júlio Coelho ${ }^{7}$, Ana Teresa Serra ${ }^{1,8}{ }^{(D)}$ and Maria R. Bronze ${ }^{1,3,8, *}$
}

1 iBET, Instituto de Biologia Experimental e Tecnológica, Apartado 12, 2781-901 Oeiras, Portugal; sheila.alves@ibet.pt (S.C.O.-A.); f.andrade@campus.ul.pt (F.A.); ines.prazeres@ibet.pt (I.P.); tserra@ibet.pt (A.T.S.)

2 DCFM, Departamento de Ciências Farmacêuticas e do Medicamento, Faculdade de Farmácia, Universidade de Lisboa, Av. das Forças Armadas, 1649-003 Lisboa, Portugal; abentosilva@ff.ulisboa.pt

3 iMed ULisboa, Instituto de Investigação do Medicamento, Faculdade de Farmácia, Universidade de Lisboa, Av. Prof. Gama Pinto, 1649-003 Lisboa, Portugal

4 INIAV, Instituto Nacional de Investigação Agrária e Veterinária, Av. da República, 2780-505 Oeiras, Portugal; jorge.capelo@iniav.pt

5 MARE, Marine and Environmental Sciences Centre, Faculdade de Ciências, Universidade de Lisboa, Grande, 1749-016 Lisboa, Portugal; baduarte@fc.ul.pt (B.D.); micacador@fc.ul.pt (I.C.)

check for updates

Citation: Oliveira-Alves, S.C.; Andrade, F.; Prazeres, I.; Silva, A.B.; Capelo, J.; Duarte, B.; Caçador, I.; Coelho, J; Serra, A.T.; Bronze, M.R. Impact of Drying Processes on the Nutritional Composition, Volatile Profile, Phytochemical Content and Bioactivity of Salicornia ramosissima J. Woods. Antioxidants 2021, 10, 1312. https://doi.org/10.3390/ antiox10081312

Academic Editors: Monica Rosa Loizzo and Rosa Tundis

Received: 17 July 2021

Accepted: 13 August 2021

Published: 20 August 2021

Publisher's Note: MDPI stays neutral with regard to jurisdictional claims in published maps and institutional affiliations.

Copyright: () 2021 by the authors. Licensee MDPI, Basel, Switzerland. This article is an open access article distributed under the terms and conditions of the Creative Commons Attribution (CC BY) license (https:// creativecommons.org/licenses/by/ $4.0 /)$.
6 Departamento de Biologia Vegetal, Faculdade de Ciências, Universidade de Lisboa, Campo Grande, 749-016 Lisboa, Portugal

7 Horta da Ria Lda., Rua de São Rui, 3830-362 Gafanha Nazaré, Portugal; geral@hortadaria.pt

8 Instituto de Tecnologia Química e Biológica António Xavier, Universidade Nova de Lisboa, Av. da República, 2780-157 Oeiras, Portugal

* Correspondence: mbronze@ibet.pt

\begin{abstract}
Salicornia ramosissima J. Woods is a halophyte plant recognized as a promising natural ingredient and will eventually be recognized a salt substitute $(\mathrm{NaCl})$. However, its shelf-life and applicability in several food matrices requires the use of drying processes, which may have an impact on its nutritional and functional value. The objective of this study was to evaluate the effect of oven and freeze-drying processes on the nutritional composition, volatile profile, phytochemical content, and bioactivity of S. ramosissima using several analytical tools (LC-DAD-ESI-MS/MS and SPME-GC-MS) and bioactivity assays (ORAC, HOSC, and ACE inhibition and antiproliferative effect on HT29 cells). Overall, results show that the drying process changes the chemical composition of the plant. When compared to freeze-drying, the oven-drying process had a lower impact on the nutritional composition but the phytochemical content and antioxidant capacity were significantly reduced. Despite this, oven-dried and freeze-dried samples demonstrated similar antiproliferative $(17.56 \mathrm{mg} / \mathrm{mL}$ and $17.24 \mathrm{mg} / \mathrm{mL}$, respectively) and antihypertensive $(24.56 \mathrm{mg} / \mathrm{mL}$ and $18.96 \mathrm{mg} / \mathrm{mL}$, respectively) activities. The volatile composition was also affected when comparing fresh and dried plants and between both drying processes: while for the freeze-dried sample, terpenes corresponded to $57 \%$ of the total peak area, a decrease to $17 \%$ was observed for the oven-dried sample. The oven-dried $S$. ramosissima was selected to formulate a ketchup and the product formulated with $2.2 \%(w / w)$ of the oven-dried plant showed a good consumer acceptance score. These findings support the use of dried S. ramosissima as a promising functional ingredient that can eventually replace the use of salt.
\end{abstract}

Keywords: flavonoids; antioxidants; minerals; volatile compounds; hypertension

\section{Introduction}

Halophyte plants are naturally evolved salt-tolerant plants commonly found in saltmarshes and coastal areas worldwide, representing at most $2 \%$ of terrestrial plant species [1,2]. Among steam succulent halophytes, Salicornia species are evolved into 
physiological forms that allow them to cope with excessive salinity, high temperature amplitudes, and elevated irradiances through the production of osmoprotective, antioxidant, and photoprotective metabolites [3,4], making them ideal candidates for bioprospection of added-value compounds.

The annual edible halophyte Salicornia ramosissima J. Woods, also known as glasswort and sea asparagus, belongs to the Amaranthaceae family and is widespread on the saltmarshes of the Iberian Peninsula $[5,6]$. This specie has been introduced into the European market as a vegetable with leafless shoots due to its slight salty taste, which is appreciated in gourmet cuisine as a promising salt substitute [7-9].

Nutritionally, S. ramosissima is a source of proteins, fibers, minerals, and polyunsaturated fatty acids. Among phytochemicals, phenolic compounds $[7,10]$ such as quercetin3-O-glucoside and caffeoylquinic acids were already identified in S. ramosissima. These compounds are known to play an important role in the prevention of different disorders such as cancer, hypertension, and cardiovascular diseases [11-14]. Studies state that the phenolic compounds from S. ramosissima display antioxidant activity and a photoprotective effect against UV radiation [15], and have a therapeutic value on the male reproductive system [16].

Currently, S. ramosissima has been recognized as a promising candidate for the food industry through its applicability as a natural ingredient for the development of new products with functional and beneficial health properties [17-20]. However, fresh S. ramosissima is sensitive to microbial spoilage even when refrigerated, thus necessary to freeze or dry to extend its shelf-life [21]. The agroindustry has applied the oven-drying process, one of the most widely used preservation methods, in genus Salicornia as the preservation method to allow for its use as a condiment or ingredient in foods. However, the impact on the nutritional and phytochemical content after the drying process of fresh S. ramosissima has not been investigated. According to a study that applied a convective drying process between 40 and $70{ }^{\circ} \mathrm{C}$ to Sarcocornia perennis, the drying at $70{ }^{\circ} \mathrm{C}$ proved to be the most appropriate methodology to preserve its health-beneficial properties [21].

The present study aimed to evaluate the effect of two drying processes (oven and freeze-drying) on the quality attributes and bioactivity of $S$. ramosissima. Several analytical methods, enzymatic assays, and cell-based studies were used to compare the nutritional content, phenolic composition, antioxidant activity, antihypertensive effect, and antiproliferative capacity of the dried plants. For the first time, the volatile composition of this plant (fresh and dried) was described and its acceptance was evaluated after formulation in a food product.

\section{Materials and Methods}

\subsection{Halophyte Plant}

Fresh and oven-dried Salicornia ramosissima J. Woods were obtained from Horta da Ria Lda. (Aveiro, Portugal). The fresh plants were collected in high saltmarsh between July and October 2019 in the region of Aveiro (north of Portugal). Upon reception, a portion of fresh plants was stored in plastic bags at $7{ }^{\circ} \mathrm{C}$ until its volatile, nutritional, and phytochemical analyses were performed. Another portion of fresh plants was stored in plastic bags at $-20{ }^{\circ} \mathrm{C}$ for subsequent freeze-drying. Taxonomic identity of specimens was based on morphological and morphometric features following the criteria of Valdés and Castroviejo (1990) [22].

\subsection{Drying Process}

The freeze-drying process of the $S$. ramosissima was carried out by first grinding (Grinder Mill Flama, Aveiro, Portugal) the whole fresh frozen plants in liquid nitrogen (fast freezing) and then lyophilizing (ScanVac, Coolsafe 95/55-80 freeze dryer, Lynge, Denmark) for $24 \mathrm{~h}$ (moisture $<3.5 \%$ ). According to the producer, the oven-dried S. ramosissima production was accomplished by placing the whole fresh plants into a dry oven at $70{ }^{\circ} \mathrm{C}$ for $72 \mathrm{~h}$. After drying, the whole oven-dried plants were packed in colorless plastic bags 
and sent to the laboratory. In the laboratory, the whole oven-dried plant was ground using a mill (Cyclone mill, Retsch Twister, Haan, Germany), homogenized, and packed in amber glass bottles. The oven-dried and freeze-dried S. ramosissima were stored in amber glass bottles at $-20^{\circ} \mathrm{C}$ until analyses.

\subsection{Reagents}

Acetonitrile $\left(\mathrm{CH}_{3} \mathrm{CN}, 99.9 \%\right.$ LC-MS) and methanol (MeOH, 99.8\% LC-MS) were purchased from Fisher Scientific (Thermo Fisher Scientific, Waltham, MA, USA). The formic acid ( $\mathrm{HCOOH}, 98 \%$ p.a.) was purchased from Merck (Darmstadt, Germany). The ultra-pure water (18.2 MO.cm) was obtained from a Millipore-Direct Q3 UV system (Millipore, Burlington, MA, USA). Fluorescein sodium salt, Folin-Ciocalteu's reagent Trolox (6-hydroxy-2,5,7,8-tetramethyl chromane-2-carboxylic acid) and AAPH (2,2-azobis(2methylpropionamidine)dihydrochloride), were all obtained from Sigma-Aldrich (Darmstadt, Germany). Standard phenolic compounds, namely gallic acid (PubChem CID: 370) and quercetin-3-glucoside (PubChem CID: 25203368), were obtained from Sigma-Aldrich (Darmstadt, Germany), and chlorogenic acid (PubChem CID: 1794427) and quercetin-3O-(6-acetylglucoside) were obtained from Extrasynthese (Genay, France). MTS reagent (CellTiter $96^{\circledR}$ AQueous One Solution Reagent) was obtained from Promega (Madison, WI, USA).

\subsection{Nutritional Characterization}

\subsubsection{Nutritional Parameters}

Moisture was determined in an oven-drying at $105 \pm 1{ }^{\circ} \mathrm{C}$ and ash content was quantified by means of sample incineration in a muffle furnace $\left(600^{\circ} \mathrm{C}\right)$ as described by the Association of Official Analytical Chemists [23]. Total protein was determined by the Kjeldahl method $(\mathrm{F}=6.25)$ and total fat using the Soxhlet extraction method [23]. Total energy value was calculated according to the European Regulation 1169/2011 (European Parliament and Council of the European Union, 2006). Total dietary fiber was determined according to the AOAC official method 985.29 [23]. The fatty acids composition of the sample was analyzed by gas chromatography (GC) with a flame ionization detector (FID). The fatty acids methyl esters (FAMEs) were performed as described by the AOCS method Ce 2-66 [23]. FAMEs were identified by comparison of retention times with FAMEs standard mixture under the same conditions (FAME Mix C4-C24 Sulpeco, Bellefonte, PA, USA) and quantified using area normalization. Carbohydrates were calculated by difference using Equation (1). All the measurements were performed in triplicates for each analysis.

$$
[\text { Carbohydrates }=100-(\text { Ash }+ \text { Moisture }+ \text { Protein }+ \text { Total fat })]
$$

\subsubsection{Mineral Composition}

The mineral composition of fresh S. ramosissima was determined by Flame Atomic Absorption Spectrometry (FAAS) [23]. Minerals of dried S. ramosissima were extracted by the digestion process and quantified using total X-ray fluorescence spectroscopy (TXRF) element analysis [24]. This procedure of digestion was carried out in Teflon reactors: $200 \mathrm{mg}$ of the sample were weighted into digestion reactors and $0.3 \mathrm{~mL} \mathrm{HClO}_{4}$ and $1.7 \mathrm{~mL}$ $\mathrm{HNO}_{3}$ were added. The reactors were tightly closed and digestion occurred during $3 \mathrm{~h}$ in an oven at $110^{\circ} \mathrm{C}$ [25]. After cooling, for each sample, $496 \mu \mathrm{L}$ were recovered into $1.5 \mathrm{~mL}$ tubes and $2 \mu \mathrm{L}$ of $\mathrm{Ga}$ (final concentration $1 \mathrm{mg} \mathrm{L}^{-1}$ ) was added as the internal standard for mineral quantification, spiked with $2 \mu \mathrm{L} \mathrm{Cd}$ (final concentration $1 \mathrm{mg} \mathrm{L}^{-1}$ ) [26]. Samples were stored at $4{ }^{\circ} \mathrm{C}$ until analysis. Mineral quantification was determined through total $X$-ray fluorescence spectroscopy (TXRF) element analysis. The cleaning and preparation of the TXRF quartz glass sample carriers were performed and $5 \mu \mathrm{L}$ of the digested sample was added to the center of the carrier [26]. The carriers with the samples were aligned in a support containing a carrier with arsenic for gain correction (mono-element standard, Bruker Nano GmbH, Karlsruhe, Germany), a carrier with a nickel standard for sensitivity 
and detection limit (mono-element standard, Bruker Nano GmbH, Karlsruhe, Germany), and a carrier with a multi-element kraft for quantification accuracy (Kraft 10, Bruker Nano GmbH, Karlsruhe, Germany). Element measurements were carried out in a portable benchtop TXRF instrument (S2 PICOFOX ${ }^{\mathrm{TM}}$ spectrometer, Bruker Nano GmbH) for $800 \mathrm{~s}$ per sample. The accuracy and precision of the analytical methodology for elemental determinations were assessed by replicate analysis of certified reference material (BCR-146). Blanks and the concurrent analysis of the standard reference material were used to detect possible losses/contamination during analysis. The TXRF spectra and data evaluation interpretation were accomplished using the Spectra 7.8.2.0 software (Bruker Nano GmbH, Berlin, Germany).

\subsection{Volatile Composition by Gas Chromatography}

Solid phase microextraction (SPME) was used for the analysis of volatile compounds from fresh and dried plants. Briefly, the fresh S. ramosissima was crushed with a mortar and pestle until a paste was formed, after which $1.5 \mathrm{~g}$ of paste was transferred to a GC-MS vial. For the dried plants, $0.5 \mathrm{~g}$ was transferred directly to a GC-MS vial. A 20 mL headspace vial (La-Pha-Pack ${ }^{\circledR}$, Langerwehe, Germany) capped with a white PTFE silicone septum (Specanalitica, Carcavelos, Portugal) was used in both situations. The SPME operating conditions consisted of an extraction temperature of $40{ }^{\circ} \mathrm{C}$ for $40 \mathrm{~min}$, a rotating speed of $250 \mathrm{rpm}$, an agitation of $10 \mathrm{~s}$, and desorption time of $3 \mathrm{~min}$ at $250{ }^{\circ} \mathrm{C}$. Analyses were performed in a GCMS QP2010 Plus (Shimadzu, Kyoto, Japan) equipped with an AOC-5000 autosampler $\left(\right.$ Shimadzu $\left.{ }^{\circledR}\right)$. For headspace, SPME sampling used a divinylbenzene/carboxen/polydimethylsiloxane (DVB/Car/PDMS) fiber (Supelco Analytical, Bellefonte, PA, USA). For the separation of volatile compounds, a capillary column Sapiens-5-MS (Teknokroma, Barcelona, Spain) with dimensions of $30 \mathrm{~m}, 0.25 \mathrm{~mm}$ (IS), and $0.25 \mu \mathrm{m}$ (film thickness) was used. The working conditions were as follows. The injector and detector temperature were maintained at $250{ }^{\circ} \mathrm{C}$. The injection mode was carried out in the splitless mode during $1.5 \mathrm{~min}$ and high-purity helium $(\geq 99.999 \%)$ was used as the carrier gas. The column oven temperature was kept at an initial temperature of $40{ }^{\circ} \mathrm{C}$ for $5 \mathrm{~min}$, increased to $170{ }^{\circ} \mathrm{C}$ at a rate of $5^{\circ} \mathrm{C} \mathrm{min}-1$, and then was increased to $230{ }^{\circ} \mathrm{C}$ at $30^{\circ} \mathrm{C} \mathrm{min}^{-1}$ and maintained for $4 \mathrm{~min}$; carrier gas (He) was maintained with a flow of $2.00 \mathrm{~mL} \mathrm{~min}^{-1}$. In the MS interface, the temperature was $250{ }^{\circ} \mathrm{C}$ and the ion source temperature was $250{ }^{\circ} \mathrm{C}$. Mass spectra were acquired in the electron ionization (EI) mode at $70 \mathrm{eV}$ in a $m / z$ range between 29 and 300 with a scan speed of 588 scans s$^{-1}$. Identification of compounds was performed using the mass spectra library (NIST 2005 mass spectra database, Boulder, CO, USA) and Linear Retention Index (RI) [27,28]. Each sample was analyzed in duplicates.

\subsection{Analysis of Phenolic Composition}

\subsubsection{Extraction of Phenolic Compounds}

The extraction of phenolic compounds was performed using an ultrasound extraction procedure (USE) $[18,19]$. Briefly, the fresh plant was crushed with a mortar and pestle with the addition of liquid nitrogen, whereas the dried plant was ground in a cyclone mill (Retsch Twister). The extractions were performed by adding $100 \mathrm{~mL}$ of ethanol:water $(80: 20, v / v)$ solution to $10 \mathrm{~g}$ of the fresh plant or $2 \mathrm{~g}$ of the dried plant, respectively. The samples were placed in the vortex for $10 \mathrm{~s}$ and then immediately transferred to an ultrasonic water bath (ArgoLab DU-100, Carpi, Modena, Italy) at $40 \mathrm{kHz}$ and $220 \mathrm{~W}$ for $60 \mathrm{~min}$ at $25 \pm 3{ }^{\circ} \mathrm{C}$. The samples were then centrifuged at $6000 \times g$ for $15 \mathrm{~min}$ (Sorvall ST16 centrifuge, Thermo Scientific, Osterode, Germany) and the supernatant removed. The supernatant was evaporated to dryness at $40 \pm 1{ }^{\circ} \mathrm{C}$ under reduced pressure (120 Bar) using a rotavapor (Büchi R-114, Flawil, Switzerland). The dried residue was dissolved in $2 \mathrm{~mL}$ of ethanol:water $(50: 50, v / v)$ solution, filtered through a $0.22 \mathrm{~mm}$ SFCA membrane Branchia (Labbox Labware, Barcelona, Spain), and stored at $-18{ }^{\circ} \mathrm{C}$ until analysis. All extractions were carried out in triplicates. 


\subsubsection{HPLC-DAD-ESI-MS/MS}

In order to characterize the phenolic composition, the extracts were analyzed in a Waters Alliance 2695 HPLC system (Waters, Milford, MA, USA) equipped with a quaternary pump, solvent degasser, auto sampler, and column oven, coupled to a diode array detector (DAD), namely the Detector Waters 2996 (Waters, Milford, MA, USA). For the separation of compounds, a pre-column (100RP-18, $5 \mathrm{~mm}$ ) and reversed phase C18 column (LiCrospher $100 \mathrm{RP}-18,250 \times 4 \mathrm{~mm} ; 5 \mathrm{~mm}$ ) in a thermostatic oven at $35^{\circ} \mathrm{C}$ were used. The mobile phase consisted of water:formic acid (99.5\%:0.5\%) as eluent A and acetonitrile:formic acid (99.5\%:0.5\%) as eluent $\mathrm{B}$ at a flow rate of $0.30 \mathrm{~mL} / \mathrm{min}$. All solvents were filtered through a $0.22 \mathrm{~mm}$ PVDF membrane (Millipore, Billerica, MA, USA) prior to analysis. The system was run with the following gradient elution program: 0-10 min from 99 to $95 \%$ A; 10-30 min from 95 to $82 \% \mathrm{~A} ; 30-44 \mathrm{~min}$ from 82 to $64 \% \mathrm{~A} ; 44-64 \mathrm{~min}$ at $64 \% \mathrm{~A} ; 64-90 \mathrm{~min}$ from 64 to $10 \% \mathrm{~A} ; 90-100 \mathrm{~min}$ at $10 \% \mathrm{~A} ; 100-101 \mathrm{~min}$ from 10 to $95 \% \mathrm{~A} ; 101-120 \mathrm{~min}$ at $95 \% \mathrm{~A}$; and finally returning to the initial conditions. The injection volume was $20 \mu \mathrm{L}$. DAD was used to scan the wavelength absorption from 200 to $650 \mathrm{~nm}$. Tandem mass spectrometry (MS/MS) detection was performed using an electrospray ionization source (ESI) at $120^{\circ} \mathrm{C}$ and applying a capillary voltage of $2.5 \mathrm{kV}$ and cone voltage of $30 \mathrm{~V}$. The compounds were ionized in the negative mode and spectra were recorded in the range of $m / z 60-1500$. Analytical conditions were optimized to maximize the precursor ion signal $\left([\mathrm{M}-\mathrm{H}]^{-}\right)$. Ultra-high purity argon (Ar) was used as a collision gas. High purity nitrogen $\left(\mathrm{N}_{2}\right)$ was used both as a drying gas and nebulizing gas. For data acquisition and processing, MassLynx software (version 4.1,Waters Corporation, Milford, MA, USA) was used.

\subsubsection{HPLC-DAD}

The phenolic compounds were quantified using a UHPLC Vanquish (Thermo Fisher Scientific, Waltham, MA, USA) equipped with an auto-sampler, pump, and Vanquish diode array detector (DAD). The chromatographic separation of compounds was carried on a Luna C18 reversed phase (Luna $5 \mu \mathrm{m}$ C18 (2) $100 \AA$, $250 \times 4$ mm; Phenomenex) and a Manu-cart RP-18 pre-column in a thermostatic oven at $35^{\circ} \mathrm{C}$. DAD was programmed for a scanning between 192 and $798 \mathrm{~nm}$ at a speed of $1 \mathrm{~Hz}$ with a bandwidth of $5 \mathrm{~nm}$. The detection was monitored using three individual channels $(280,320$, and $360 \mathrm{~nm})$ at a speed of $10 \mathrm{~Hz}$ with a bandwidth of $11 \mathrm{~nm}$. The auto sampler's temperature was set at $12{ }^{\circ} \mathrm{C}$ and the injection volume applied was $20 \mu \mathrm{L}$. The mobile phase consisted of water:formic acid (99.5\%:0.5\%) as eluent $\mathrm{A}$ and acetonitrile:formic acid (99.5\%:0.5\%) as eluent $B$ at a flow rate of $0.30 \mathrm{~mL} / \mathrm{min}$. All solvents were filtered through a $0.22 \mu \mathrm{m}$ PVDF membrane (Millipore, Billerica, MA, USA) prior to analysis. The system was run with the following gradient program: 0-10 min from 99 to $95 \%$ A; 10-30 min from 95 to $82 \% \mathrm{~A} ; 30-44 \mathrm{~min}$ from 82 to $64 \% \mathrm{~A} ; 44-64 \mathrm{~min}$ at $64 \% \mathrm{~A} ; 64-90 \mathrm{~min}$ from 64 to $10 \% \mathrm{~A}$; 90-100 $\mathrm{min}$ at $10 \% \mathrm{~A} ; 100-101 \mathrm{~min}$ from 10 to $95 \% \mathrm{~A} ; 101-120 \mathrm{~min}$ at $95 \% \mathrm{~A}$; and finally returning to the initial conditions. The quantification of the phenolic compounds was performed by a calibration curve $(0.78-100 \mathrm{ppm})$ obtained with gallic acid, chlorogenic acid, and quercetin-3-hexoside. The data acquisition system was the Chromeleon version 7.0 (Waltham, MA, USA) for DAD.

\subsection{Total Phenolic Content}

The total phenolic content (TPC) of the extracts was determined according to the Folin-Ciocalteu's colorimetric method [29,30]. Briefly, $230 \mu \mathrm{L}$ of milli-Q water, $10 \mu \mathrm{L}$ of the extract, and $15 \mu \mathrm{L}(0.25 \mathrm{~N})$ of Folin-Ciocalteu's reagent were added in the microplate and mixed at room temperature for $3 \mathrm{~min}$. After, $45 \mu \mathrm{L}$ of sodium carbonate solution (solution 35\%) was added and the microplate was incubated for $1 \mathrm{~h}$ at room temperature in the dark. The absorbance of the samples was measured at $765 \mathrm{~nm}$ on a microplate spectrophotometer (Epoch2, Biotek (Winooski, VT, USA)) with the Gen5 3.02 data analysis software spectrophotometer. Gallic acid $(1000 \mathrm{mg} / \mathrm{L})$ was used as the standard for the 
calibration curve and the results were expressed as gallic acid equivalents (mg GAE/g). All measurements were performed in triplicates for each sample analyzed.

\subsection{Antioxidant Activity}

\subsubsection{Oxygen Radical Absorbance Capacity (ORAC) Assay}

The ORAC assay was performed following a modified method [31] as described by Serra and collaborators (2011) [32] using a microplate fluorescent reader (FL800 Bio-Tek Instruments, Winooski, VT, USA). This assay assessed the ability of the antioxidant species in the sample to inhibit the oxidation of fluorescein $\left(3 \times 10^{-4} \mathrm{mM}\right)$ catalyzed by peroxyl radicals generated from AAPH. Trolox was used as a reference standard and the results were expressed as Trolox equivalent antioxidant capacity (TEAC) per gram of the plant $(\mu \mathrm{mol}$ TEAC $/ \mathrm{g})$. Experiments were performed in triplicates for each sample analyzed.

\subsubsection{Hydroxyl Radical Scavenging Capacity (HOSC) Assay}

The HOSC assay was based on the previous reported method [33] using the FL800 microplate fluorescence reader (FL800 Bio-Tek Instruments, Winooski, VT, USA). This assay measured the hydroxyl radical scavenging capacity of a sample using fluorescein $\left(9.96 \times 10^{-8} \mathrm{M}\right)$ as a probe and a classic Fenton reaction with $\mathrm{FeCl}_{3}(3.42 \mathrm{mM})$ and $\mathrm{H}_{2} \mathrm{O}_{2}$ $(0.20 \mathrm{M})$ as a source of hydroxyl radicals. Samples were analyzed in triplicates and results were expressed as Trolox equivalents antioxidant capacity (TEAC) per gram of the plant $(\mu \mathrm{mol} \mathrm{TEAC/g})$.

\subsection{Antihypertensive Activity Assay}

The antihypertensive activity of $S$. ramosissima extracts was evaluated using an angiotensinconverting enzyme (ACE) activity assay kit (Sigma-Aldrich, Saint Louis, MO, USA). This kit provides a simple, quick, sensitive, and direct procedure for measuring ACE levels to screen for ACE inhibitors and this assay is based on the cleavage of a synthetic fluorogenic peptide. Briefly, $10 \mu \mathrm{L}$ of extract and $40 \mu \mathrm{L}$ of ACE was added to a 96-well black microplate and incubated at $37^{\circ} \mathrm{C}$ for $5 \mathrm{~min}$ to allow for contact between the enzyme and the inhibitor. Then, $50 \mu \mathrm{L}$ of the substrate (ACE fluorogenic) were added and the fluorescence was read every minute for $5 \mathrm{~min}$. A standard curve ( 0.1 to $0.8 \mathrm{nmol}$ ) was used for the quantification of the fluorescent product formed and the percentage of inhibition was calculated according to the manufacturer's protocol (CS0002, Sigma-Aldrich). Lisinopril (Sigma-Aldrich, Darmstadt, Germany) was also used as a positive control. The $\mathrm{IC}_{50}$ value corresponds to the needed amount of extract to inhibit $50 \%$ of the ACE. The range of concentrations tested was between 500 and $31.25 \mathrm{mg} / \mathrm{mL}$ ( 59 to $3.68 \mathrm{mg} / \mathrm{mL} \mathrm{dw}$ ) for the extract from the fresh plant, and between 100 and $3.125 \mathrm{mg} / \mathrm{mL}$ for the extracts from the dried plants.

\subsection{Cell-Based Assays}

\subsubsection{Cell Culture}

Human colon cancer cell lines, namely HT29 and Caco-2 cells, were obtained from the American Type Culture Collection (ATCC, Manassas, VA, USA) and Deutsche Sammlung von Microorganismen und Zellkulturen (Barunshweig, Germany), respectively. Both cell lines were grown in RPMI 1640 medium (Gibco, Carlsbad, CA, USA) supplemented with $10 \%(v / v)$ of heat-inactivated sterile filtered fetal bovine serum (FBS; Biowest, Riverside, CA, USA). For Caco-2 cells, its culture medium was supplemented with $1 \%(v / v)$ of PenStrep (Gibco, Carlsbad, CA, USA). Stock cells were maintained as monolayers in $75 \mathrm{~cm}^{2}$ culture flasks and incubated at $37^{\circ} \mathrm{C}$ with $5 \% \mathrm{CO}_{2}$ in a humidified atmosphere. 


\subsubsection{Cytotoxicity Assay in Caco-2 Cells}

Cytotoxicity assays were performed using confluent and non-differentiated Caco-2 cells. Briefly, cells were seeded at a density of $2 \times 10^{4}$ cells/well in 96-well plates and allowed to grow for 7 days with medium renewal every $48 \mathrm{~h}$ [34]. At day 7, (complete confluence), Caco-2 cells were incubated with different concentrations of extracts, diluted in culture medium (RPMI medium with 0.5\% FBS (Gibco, Carlsbad, CA, USA)). The range of concentrations tested was $31-500 \mathrm{mg} / \mathrm{mL}(3.7-59 \mathrm{mg} / \mathrm{mL} \mathrm{dw})$ for the extract from the fresh plant and $3.1-100 \mathrm{mg} / \mathrm{mL}$ for the extracts from the dried plants. The control of the solvent $(50 \%$ of EtOH: $\mathrm{H}_{2} \mathrm{O}, v / v$ ) diluted in the culture medium (RPMI medium with $0.5 \%$ FBS) was also tested. After $24 \mathrm{~h}$ of incubation at $37^{\circ} \mathrm{C}$ with $5 \% \mathrm{CO}_{2}$ in a humidified atmosphere, the cell viability was assessed using the CellTiter $96^{\circledR}$ AQueous One Solution Cell Proliferation Assay (Promega, Madison, WI, USA) containing the MTS reagent according to manufacturer's instructions. Absorbance was measured at $490 \mathrm{~nm}$ using a microplate spectrophotometer (Epoch 2, BioTek Instruments, Inc. (Winooski, VT, USA)). Results were expressed in terms of the percentage (\%) of cellular viability relative to control (cells growth in culture medium only). At least three independent experiments were performed in triplicates.

\subsubsection{Antiproliferative Assay in HT29 Cells}

The antiproliferative effect of plants was evaluated by testing their capacity in inhibiting the proliferation of HT29 cells as described previously, a cell line widely used as a model of in vitro colorectal cancer [32,35]. Briefly, cells were cultured in 96-well microplates at a density of $1 \times 10^{4}$ cells/well. After $24 \mathrm{~h}$ of incubation at $37^{\circ} \mathrm{C}$ in $5 \% \mathrm{CO}_{2}$, the medium of each well was replaced by a medium containing the extracts prepared in the $\mathrm{EtOH}$ solution (EtOH: $\left.\mathrm{H}_{2} \mathrm{O}, 50: 50, v / v\right)$ and diluted in culture medium (RPMI medium with $0.5 \%$ FBS (Gibco, Carlsbad, CA, USA)). A control of the solvent $\left(50 \%\right.$ of $\left.\mathrm{EtOH}: \mathrm{H}_{2} \mathrm{O}, v / v\right)$ diluted in culture medium (RPMI with $0.5 \%$ FBS) was also tested. The range of concentrations tested was 31 to $500 \mathrm{mg} / \mathrm{mL}$ ( 59 to $3.68 \mathrm{mg} / \mathrm{mL} \mathrm{dw}$ ) for the extract from the fresh plant and 100 to $3.125 \mathrm{mg} / \mathrm{mL}$ for the extracts from the dried plants. A control of the solvent ( $50 \%$ of EtOH: $\mathrm{H}_{2} \mathrm{O}, v / v$ ) diluted in culture medium (RPMI medium with $0.5 \%$ FBS) was also tested. Cells were incubated for $24 \mathrm{~h}$ with concentrations of the extracts, and after $24 \mathrm{~h}$, the medium was removed and the cell viability was determined by MTS reagent as reported in the cytotoxicity tests. Results were expressed in terms of the percentage $(\%)$ of cellular viability relative to the control (cells growth in culture medium only). The amount of sample necessary to decrease $50 \%$ of the cellular viability, the $\mathrm{EC}_{50}$ (effective dose), was calculated. Experiments were performed in triplicates using at least three independent assays.

\subsection{Sensory Analysis}

The sensorial testing aimed to assess the acceptance and purchase intention of consumers for ketchup samples prepared with dried S. ramosissima. Two ketchup formulations were tested containing different amounts of oven-dried S. ramosissima as a salt substitute (an alternative to sodium chloride): (I) $2.2 \%$ (0.91 g of salt per $100 \mathrm{~g}$ of product) and (II) $3.0 \%$ (1.38 g of salt per $100 \mathrm{~g}$ of product). The samples were produced by Mendes Gonçalves S.A. (Golegã, Portugal) by homogenizing the tomato products with S. ramosissima and other natural ingredients. The acceptability testing was conducted with 102 consumers. The participants filled out a questionnaire assessing consumption information and food preferences. The consumers received the samples to evaluate attributes including appearance, aroma, and taste as well as their overall liking. Consumers rated the sensory characteristics of the products on a nine-point hedonic scale: $1=$ "disliked extremely", $2=$ "disliked very much", 3 = "disliked moderately", $4=$ "disliked slightly", $5=$ "neither liked nor disliked", 6 = "liked slightly", 7 = "liked moderately", $8=$ "liked very much", and $9=$ "liked extremely". The purchase intention was also evaluated by participants, so they chose the option that best fitted their intention ("would not buy", "would maybe buy", and "would buy"). Samples were coded with 3-digit numbers and sample presentation 
was counterbalanced over the entire test to avoid order effects. Each sample $(10 \mathrm{~mL})$ was served in a plastic cup $(30 \mathrm{~mL})$ with a mini plastic spoon. Participants were instructed to drink water before and after each tasting.

\subsection{Statistical Analysis}

Results from chemical analysis were expressed as average \pm standard deviation and statistical analysis was performed using GraphPad Prism 9.4 software (GraphPad Software, Inc., La Jolla, CA, USA) for one way analysis of variance (ANOVA), Tukey's Test, and $t$-Test $(p<0.05)$. The correlation between TPC and antioxidant activity was determined with Pearson's correlation coefficient test, considering a confidence level of $95 \%(p<0.05)$. For antihypertensive and antiproliferative assays, the $\mathrm{IC}_{50}$ and $\mathrm{EC}_{50}$ values were calculated using non-linear regression (dose-response inhibition). The scheme of the analyses and bioactivity assays is shown in Figure 1.

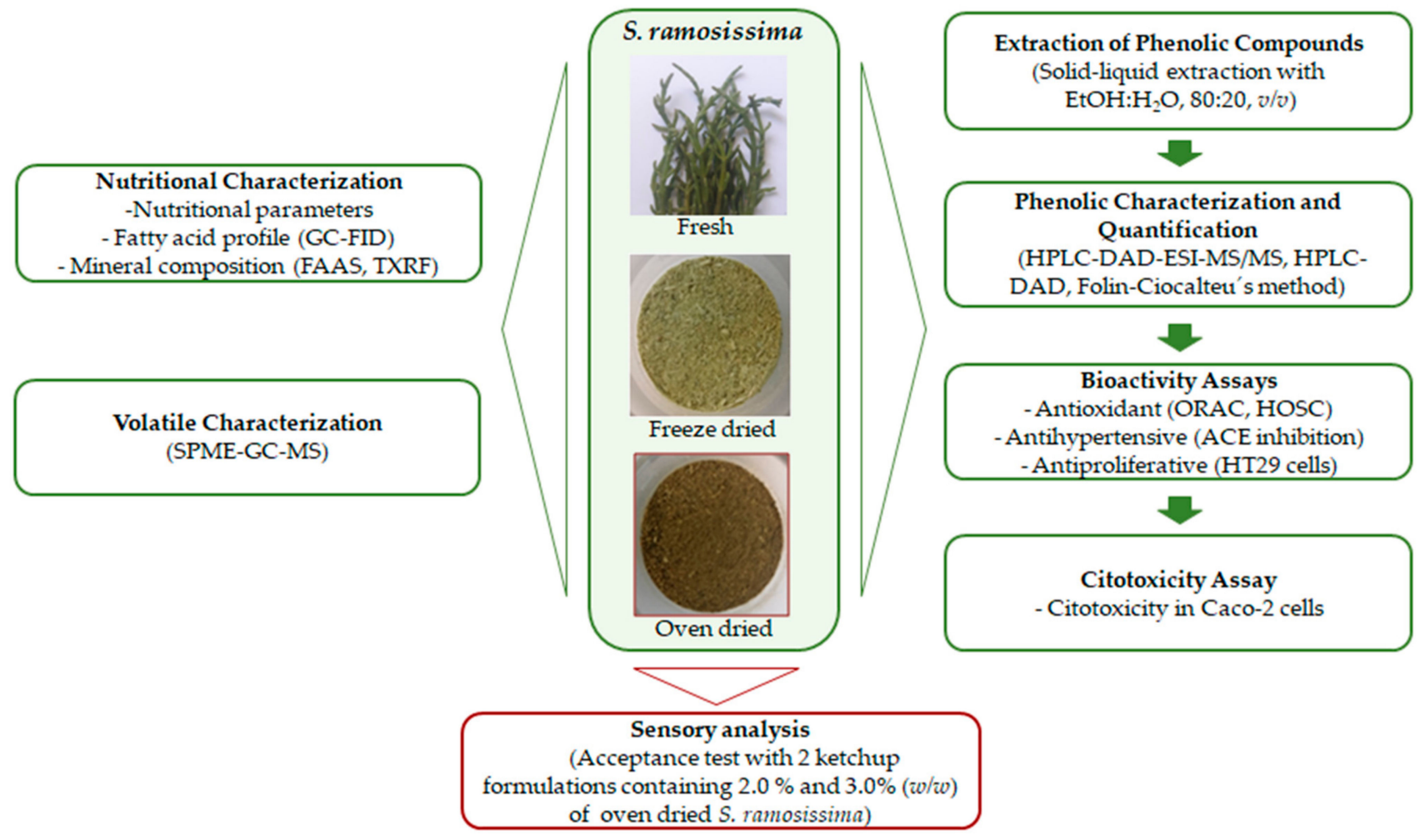

Figure 1. Scheme of the analyses and bioactivity assays of the fresh, oven, and freeze-dried S. ramosissima.

\section{Results and Discussion}

\subsection{Nutritional Characterization}

In Table 1, the nutritional composition of fresh and dried S. ramosissima samples are presented. The results obtained for the fresh plant are in accordance with data already reported in the literature [10]. For all the parameters presented in Table 1, there were differences between the fresh (values reported as dried weight) and dried plants. 
Table 1. Nutritional parameters and fatty acids of the fresh, oven, and freeze-dried S. ramosissima.

\begin{tabular}{|c|c|c|c|c|}
\hline \multirow[t]{2}{*}{ Sample } & \multicolumn{2}{|c|}{ Fresh } & \multirow{2}{*}{$\begin{array}{l}\text { Oven-Dried } \\
(\mathrm{g} / 100 \mathrm{~g} \mathrm{dw})\end{array}$} & \multirow{2}{*}{$\begin{array}{c}\text { Freeze-Dried } \\
(\mathrm{g} / 100 \mathrm{~g} \mathrm{dw})\end{array}$} \\
\hline & $(\mathrm{g} / 100 \mathrm{~g} \mathrm{fw})$ & $(g / 100 g d w)^{d}$ & & \\
\hline \multicolumn{5}{|l|}{ Nutritional parameters ${ }^{a b}$} \\
\hline Moisture & $88.20 \pm 0.88$ & - & $7.66 \pm 0.08^{a}$ & $3.20 \pm 0.03^{b}$ \\
\hline Ashes & $5.91 \pm 0.24$ & $50.08 \pm 0.34^{\mathrm{A}}$ & $41.00 \pm 1.64^{\mathrm{aB}}$ & $44.20 \pm 1.77^{\mathrm{aB}}$ \\
\hline Protein & $1.59 \pm 0.06$ & $13.47 \pm 0.51^{\mathrm{A}}$ & $8.48 \pm 0.34^{\mathrm{bC}}$ & $11.00 \pm 0.44^{\mathrm{aB}}$ \\
\hline Total fat & $0.40 \pm 0.01$ & $3.39 \pm 0.03^{\mathrm{A}}$ & $1.20 \pm 0.01^{\mathrm{aC}}$ & $1.80 \pm 0.02^{\mathrm{aB}}$ \\
\hline Carbohydrates & $2.90 \pm 0.12$ & $24.58 \pm 1.02^{\mathrm{A}}$ & $12.70 \pm 0.51^{\mathrm{aC}}$ & $12.90 \pm 0.52^{a B}$ \\
\hline Total dietary fiber & $1.00 \pm 0.03$ & $8.47 \pm 0.26^{C}$ & $29.00 \pm 0.87^{\mathrm{aA}}$ & $26.90 \pm 0.81 \mathrm{bB}$ \\
\hline Energy value (kcal/100 g) & $23.60 \pm 0.94$ & $200.01 \pm 8.00^{\mathrm{A}}$ & $153.50 \pm 6.1^{\mathrm{aC}}$ & $165.6 \pm 6.6^{\mathrm{aB}}$ \\
\hline Salt & $5.62 \pm 0.73$ & $47.63 \pm 6.20^{\mathrm{A}}$ & $36.8 \pm 4.8^{\mathrm{aAB}}$ & $28.5 \pm 3.7^{\mathrm{aB}}$ \\
\hline \multicolumn{5}{|l|}{ Fatty acids profile $a b c$} \\
\hline Palmitic acid (C16:0) & $24.00 \pm 0.01$ & $24.00 \pm 0.01^{\mathrm{B}}$ & $26.80 \pm 0.01^{\mathrm{aA}}$ & $19.80 \pm 0.01^{b C}$ \\
\hline Stearic acid (C18:0) & $2.00 \pm 0.01$ & $2.00 \pm 0.01^{\mathrm{A}}$ & $1.90 \pm 0.01^{\mathrm{aB}}$ & $1.30 \pm 0.01 \mathrm{bC}$ \\
\hline Oleic acid (C18:1) & $5.00 \pm 0.01$ & $5.00 \pm 0.01^{\mathrm{A}}$ & $3.50 \pm 0.01^{\mathrm{aB}}$ & $1.60 \pm 0.01 \mathrm{bC}$ \\
\hline Linoleic acid (C18:2) & $24.10 \pm 0.01$ & $24.10 \pm 0.01^{\mathrm{B}}$ & $23.80 \pm 0.01 \mathrm{bC}$ & $28.10 \pm 0.01^{\mathrm{aA}}$ \\
\hline Linolenic acid (C18:3) & $33.50 \pm 0.01$ & $33.50 \pm 0.01^{\mathrm{B}}$ & $27.90 \pm 0.01 \mathrm{bC}$ & $40.40 \pm 0.01^{\mathrm{aA}}$ \\
\hline Arachidic acid (C20:0) & $0.90 \pm 0.01$ & $0.90 \pm 0.01^{\mathrm{B}}$ & $1.20 \pm 0.01^{\mathrm{aA}}$ & $0.80 \pm 0.01^{\mathrm{bC}}$ \\
\hline Eicosenoic acid (C20:1) & $<0.05 *$ & $<0.05^{*}$ & $0.10 \pm 0.01^{\mathrm{a}}$ & $0.10 \pm 0.01^{\mathrm{a}}$ \\
\hline Behenic acid (C22:0) & $1.40 \pm 0.01$ & $1.40 \pm 0.01^{\mathrm{C}}$ & $4.20 \pm 0.01^{\mathrm{aA}}$ & $2.10 \pm 0.01^{b B}$ \\
\hline Lignoceric acid (C24:0) & $1.70 \pm 0.01$ & $1.70 \pm 0.01^{\mathrm{C}}$ & $2.90 \pm 0.01^{\mathrm{aA}}$ & $2.50 \pm 0.01^{b B}$ \\
\hline SFA & $34.30 \pm 0.01$ & $34.30 \pm 0.01^{\mathrm{B}}$ & $42.50 \pm 0.01^{\mathrm{aA}}$ & $28.10 \pm 0.01^{b C}$ \\
\hline MUFA & $7.30 \pm 0.01$ & $7.30 \pm 0.01^{\mathrm{A}}$ & $4.80 \pm 0.01 \mathrm{aB}$ & $3.10 \pm 0.01^{b C}$ \\
\hline PUFA & $58.40 \pm 0.01$ & $58.40 \pm 0.01^{\mathrm{B}}$ & $52.70 \pm 0.01^{b C}$ & $68.80 \pm 0.01^{\mathrm{aA}}$ \\
\hline PUFA n-6/PUFA n-3 & $0.72 \pm 0.01$ & $0.72 \pm 0.01^{\mathrm{A}}$ & $1.03 \pm 0.01 \mathrm{bB}$ & $0.70 \pm 0.01^{\mathrm{aA}}$ \\
\hline PUFA/SFA & $1.70 \pm 0.01$ & $1.70 \pm 0.01^{\mathrm{B}}$ & $1.24 \pm 0.01 \mathrm{bC}$ & $2.45 \pm 0.01^{\mathrm{aA}}$ \\
\hline
\end{tabular}

* (LOQ < $0.05 \mathrm{~g} / 100 \mathrm{~g})$. Abbreviations: SFA, total saturated fatty acids; MUFA, total monounsaturated fatty acids; and PUFA, total polyunsaturated fatty acids. ${ }^{\mathrm{a}}$ Data are expressed as average values \pm standard deviation $(n=3) .{ }^{\mathrm{b}}$ The lower-case letters $(\mathrm{a}$ and $\mathrm{b})$ correspond to the significant difference between the drying methods by unpaired $t$-test $(p<0.05)$. The upper-case letters $(A-C)$ indicate the significant differences between the fresh plant and the drying process by Tukey's test $(p<0.05)$. ${ }^{\mathrm{C}}$ Data are expressed in percentages of total methyl esters \pm standard deviation $(n=2)$. ${ }^{\mathrm{d}}$ The values were converted from fresh weight to dried weight according to the moisture content.

Steam succulent halophyte plants have a high percentage of water in their composition, with values higher than $84 \%[7,10,36]$. The freeze-drying process removed the water content from plant matrix more efficiently than the oven-dried process $(3.20 \%$ and $7.66 \%$, respectively). The long time required for oven-drying at $70{ }^{\circ} \mathrm{C}(72 \mathrm{~h})$ seals the surface capillaries of the samples, reducing the water releasing from the matrix [37]. The freezedrying process allows to remove the water from the frozen plant using both primary (unbound water removal) and secondary (bound water removal) drying, thus producing the driest end-product [38].

The content of ashes and the total fat, carbohydrates, salt, and energy value did not display significant differences between both drying processes. However, freeze-dried $S$. ramosissima showed a higher protein content $(11.00 \mathrm{~g} / 100 \mathrm{~g} \mathrm{dw})$ than the oven-dried plant $(8.48 \mathrm{~g} / 100 \mathrm{~g} \mathrm{dw})$. Freeze-drying inhibited the degradation of protein, while heat drying processing lead to protein degradation and denaturation [39].

The total dietary fiber content of S. ramosissima increased with the oven-drying process at $70{ }^{\circ} \mathrm{C}$ and these results are in accordance to others observed in halophytes [40,41] and in fruits and vegetables. This [41,42] may be due to a modification in the structure of carbohydrates, which enhanced a structural rearrangement of the insoluble polysaccharides that might result in an increased quantification of total dietary fiber [42].

The main fatty acids present in fresh $S$. ramosssima are palmitic, linoleic, and linolenic acids, with a predominant amount of polyunsaturated fatty acids (PUFA) $(58.40 \mathrm{~g} / 100 \mathrm{~g})$, mainly linolenic acid $(33.50 \mathrm{~g} / 100 \mathrm{~g})$ (Table 1$)$, and results are in accordance to data previously published $[7,43,44]$. The PUFA n-6/PUFA n-3 ratio was 0.72 in the lipophilic fraction 
of fresh S. ramosissima and corresponded, in this study, to the ratio of linoleic/linolenic acids. This ratio is important considering a n-6/n-3 ratio lower than 5 is associated with a significant decreased in the risk of cardiovascular, inflammatory, and autoimmune diseases, contributing to a more anti-inflammatory state $[45,46]$.

For the dried plants, the $S$. ramosissima processed by freeze-drying presented the highest amount of PUFA ( $68.8 \mathrm{~g} / 100 \mathrm{~g})$ and the lowest amount of saturated fatty acids (SFA) (28.1 g/100 g), while the oven-dried plant presented the lowest PUFA value (52.7 g/100 g) and the highest SFA value (42.5 g/100 g). The linoleic and linolenic acids' content for the oven-dried plant (23.8 g/100 g and $27.90 \mathrm{~g} / 100 \mathrm{~g}$, respectively) is lower compared to the freeze-dried plant $(28.0 \mathrm{~g} / 100 \mathrm{~g}$ and $40.2 \% \mathrm{~g} / 100 \mathrm{~g}$, respectively). Linoleic and linolenic acids' content is known to be decreased by thermo-oxidation when exposed to a temperature at $70{ }^{\circ} \mathrm{C}$ [47].

The mineral composition of halophytes plants is known to depend on the plant's growth zone as different amounts of the nutrients can be present in different soils. In Table 2, the values obtained for the fresh and dried plants studied are summarized. Sodium is known to be the most abundant macro-element in halophyte plants, including the Salicornia species, and its concentration increases with the increase of the cultivation media's salinity $[10,43]$.

Table 2. Mineral composition of the fresh, oven-dried, and freeze-dried S. ramosissima.

\begin{tabular}{|c|c|c|c|}
\hline Sample & $\begin{array}{c}\text { Fresh } \\
(f w)\end{array}$ & $\begin{array}{c}\text { Oven-Dried } \\
(\mathrm{dw})\end{array}$ & $\begin{array}{l}\text { Freeze-Dried } \\
(\mathrm{dw})\end{array}$ \\
\hline \multicolumn{4}{|c|}{ Macro-elements $(\mathrm{mg} / \mathrm{g})^{a b}$} \\
\hline Sodium $(\mathrm{Na})$ & $22.50 \pm 2.90$ & $147.01 \pm 14.85^{\mathrm{a}}$ & $114.02 \pm 19.11^{\mathrm{a}}$ \\
\hline Calcium (Ca) & $0.32 \pm 0.03$ & $0.237 \pm 0.003^{b}$ & $0.312 \pm 0.002^{\mathrm{a}}$ \\
\hline Potassium (K) & $1.05 \pm 0.22$ & $0.409 \pm 0.003^{a}$ & $0.411 \pm 0.002^{\mathrm{a}}$ \\
\hline \multicolumn{4}{|c|}{ Micro-elements $(\mu g / g) a b$} \\
\hline Iron $(\mathrm{Fe})$ & $37.00 \pm 0.5$ & $45.025 \pm 0.347^{b}$ & $73.145 \pm 0.442^{a}$ \\
\hline Manganese (Mn) & $2.30 \pm 0.32$ & $4.581 \pm 0.104^{\mathrm{a}}$ & $2.830 \pm 0.056^{b}$ \\
\hline Zinc $(\mathrm{Zn})$ & $6.20 \pm 0.90$ & $14.249 \pm 0.143^{a}$ & $13.727 \pm 0.094^{\mathrm{a}}$ \\
\hline Copper $(\mathrm{Cu})$ & $1.20 \pm 0.10$ & $2.507 \pm 0.045^{\mathrm{a}}$ & $2.270 \pm 0.037^{\mathrm{a}}$ \\
\hline Selenium (Se) & $<0.02 *$ & $<0.02 *$ & $<0.02 *$ \\
\hline Iodine (I) & $<0.13^{*}$ & $<0.03 *$ & $<0.03 *$ \\
\hline \multicolumn{4}{|l|}{ Heavy metals $(\mu g / g)^{a b}$} \\
\hline Arsenic (As) & $0.15 \pm 0.04$ & $0.264 \pm 0.015^{\mathrm{a}}$ & $0.273 \pm 0.019^{\mathrm{a}}$ \\
\hline Cadmium (Cd) & $0.010 \pm 0.001$ & $<0.10^{*}$ & $<0.10 *$ \\
\hline Mercury (Hg) & $<0.03 *$ & $<0.03 *$ & $<0.03 *$ \\
\hline Lead $(\mathrm{Pb})$ & $0.18 \pm 0.02$ & $1.525 \pm 0.028^{a}$ & $1.508 \pm 0.037^{\mathrm{a}}$ \\
\hline
\end{tabular}

* (LOD, limit of detection $\mu \mathrm{g} / \mathrm{g}){ }^{\mathrm{a}}$ Data are expressed as means values \pm standard deviation $(n=3) .{ }^{\mathrm{b}}$ The letters correspond to the statistical analysis performed to calculate the existence of a significant difference between both drying methods by the unpaired $t$-test $(p<0.05)$.

The mineral composition of oven-dried S. ramosissima was lower than the one previously reported for the same species collected in a different region in Portugal, which was dried in an oven at $40{ }^{\circ} \mathrm{C}$ [7]. The sodium, potassium, zinc, and copper contents from $S$. ramosissima were not significantly affected by the drying process used but a reduction in the levels of iron and calcium occurred when the plant was dried using the oven process (Table 2). Similar results were reported when Sarcocormia fruticosa [48] was oven-dried.

The genus Salicornia is defined as a metal accumulator plant that is capable of accumulating and tolerating high pollutant concentrations from salt marshes [5,49], including heavy metals, leading to potential impacts on human health and safety [24]. Therefore, according to the Recommendation (EU) 2018/464/2018, it is necessary to monitor the heavy metals and iodine and establish their maximum limit levels in seaweed and halophyte plants. Regarding heavy metals, the fresh S. ramosissima presented levels of lead and cadmium below 0.3 and $0.2 \mathrm{mg} / \mathrm{kg} \mathrm{fw}$, respectively, notably the maximum content allowed by Regulation (EU) number 1881/2006 for leaf vegetables. Similarly, arsenic levels in the 
fresh and dried S. ramosissima are lower than the maximum levels allowed in certain foods by Commission Regulation (EU) number 2015/1006 (0.2 mg/kg fw). Selenium, iodine, and heavy metals such as $\mathrm{Cd}$ and $\mathrm{Hg}$ were below the detection limit of the method of analysis in the dried plants analyzed (Table 2).

Oven-drying has been accepted as an important method of preservation, especially when taking into consideration the lower cost when compared to the freeze-drying process. Results presented showed that the oven drying process had a low impact on the nutritional composition of $S$. ramosissima, suggesting that this process could be a good option to extend its shelf-life. Furthermore, the oven-drying process may be use for large-scale industrial production as well as for micro-scale production. Overall, the drying process in the oven at $70{ }^{\circ} \mathrm{C}$ displayed a reduction on the protein, the Fe and Ca contents, and increased the dietary fiber and saturated fatty acids contents when compared with the freeze-drying process.

\subsection{Volatile Compounds Profile}

The volatile composition from fresh and dried S. ramosissima was studied by GC-MS. For the identification, the mass spectra comparison with the mass spectra bank, the retention time, and the Linear Retention Index (LRI) were determined. Compounds were classified by their chemical classes and odor descriptions according to the literature (Appendix A, Table A1). In order to compare contents, the percentage of the area of peaks compared to the total area of the chromatogram was measured.

Many chemical classes of compounds were identified in both the dried and fresh $S$. ramosissima, such as alcohols, aldehydes, carboxylic acids, esteres, furans, hydrocarbons, ketones, pyrazines, and terpenes, as summarized in Figure 2.

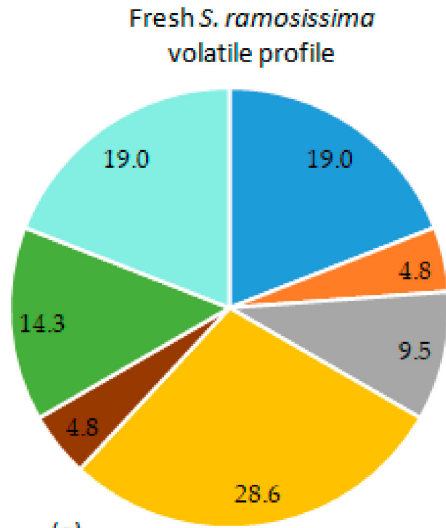

(a)

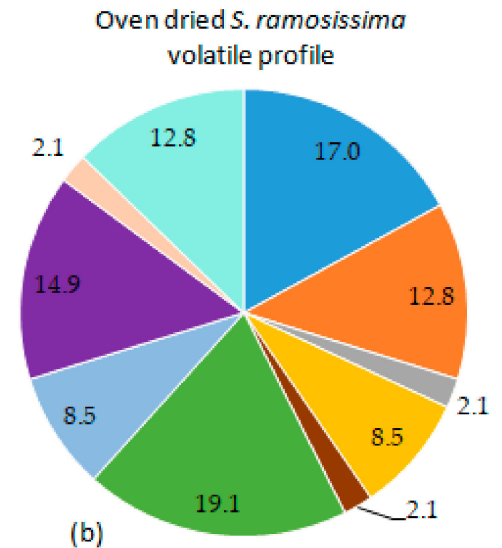

(b)

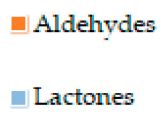

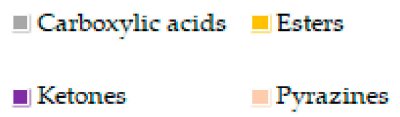

Freeze dried S. ramosissimo volatile profile
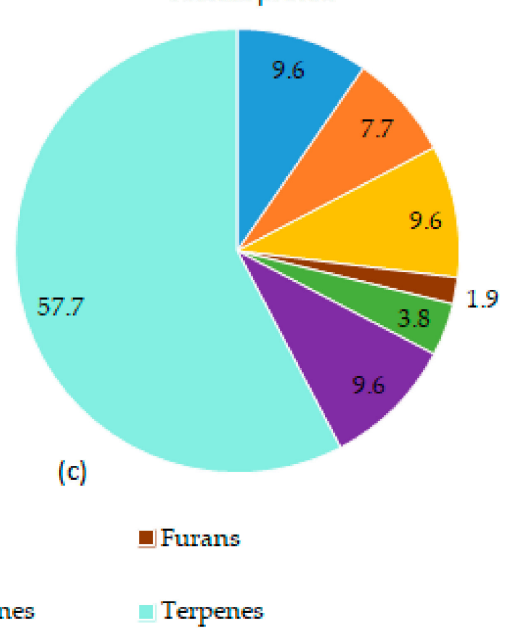

Figure 2. Pie charts showing the chemical classes profile of volatile compounds of the S. ramosissima. (a) Volatile compounds profile of fresh plant; (b) volatile compounds profile of oven-dried plant; and (c) volatile compounds profile of freeze-dried plant. 
In the fresh S. ramosissima samples, two peaks of high intensity were identified, which corresponded to 3-hexen-1-ol (47.95\%) and 1-hexanol (47.82\%). Both alcohols are known to be responsible for green-type odors and 3-hexen-1-ol has also been described as a seaweed odor [50,51]. In addition, hexanal $(0.26 \%)$, ethyl tiglate $(1.51 \%)$, 3-hexen-1-ol acetate $(0.33 \%)$, and methyl and ethyl benzoate $(0.54 \%$ and $0.21 \%$, respectively) are responsible for odors such as green, herbal, fruity, and floral [52,53].

For the oven-dried $S$. ramosissima, the main volatile compounds detected were hexanal $(34.16 \%)$, 3-hexen-1-ol (1.80\%), 2-methylbutanoic acid (7.84\%), heptanal (5.14\%), 1-octen-3-ol (3.0\%), 6-methyl-5-hepten-2-one (3.92\%), p-cymene (3.08\%), limonene (10.18\%), 3,4-dimethylcyclohexanol (7.31\%), $\beta$-cyclocitral (1.97\%), and 3,5-octadien-2-one (1.19\%). In general, linear and branched chain aldehydes contribute with herbaceous and grassygreen aromas [54], namely hexanal, which is responsible for herbal and grassy-green odors [52,53]. Compounds such as 2-methylbutanoic acid, heptanal, 1-octen-3-ol, and 3,5-octadien-2-one are described as responsible for some off-odors including sour, penetrating oil-like, mushroom-like, and marine odors, respectively, but their contribution to the aroma depends on their limit of detection $[50,53,55,56]$.

The major compounds identified in the freeze-dried $S$. ramosissima include $\beta$-myrcene (2.26\%), $\alpha$-phellandrene (8.45\%), $p$-cymene (8.80\%), 1,8-cineole (38.73\%), $\beta$-thujone $(7.21 \%)$, $\alpha$-thujone $(2.31 \%)$, camphor $(4.80 \%)$, and isobornyl acetate $(8.17 \%)$. These terpenes and esters are responsible for odors described as herbaceous, fresh, and green [57-61], specifically 1,8-cineole that has an odor description of eucalyptus, spicy, and pepper. In addition, (Z,Z)-3,6-nonadien-1-ol was identified in the freeze-dried S. ramosissima $(0.30 \%)$, which has been described as contributing to the odor of marine and seaweed of Mertensia maritima L. [50].

Both drying methods induced changes in the volatile profile compared to the fresh S. ramosissima. For the oven-dried plant, a loss of compounds such as esters, terpenes, and alcohols was observed and has been justified by the effect of the temperature [62]. Additionally, the formation of lactones, pyrazines, and ketones, and the increase of hydrocarbons and lactones, was observed. Pyrazines and ketones can be produced during the oven-drying process from free amino acids and monosaccharides by the Maillard reaction through Strecker degradation, and they contribute to the roast-like aroma and buttery flavor [63]. Conversely, lactones can be generated by the degradation of phenolic acids during the oven-drying, such as chlorogenic acids [64].

The oven-drying process significantly decreased the contribution of terpenes $(17.02 \%)$ and increased aldehydes $(12.77 \%)$ compared to the freeze-drying process. A previous study showed that alcohols such as 3-hexen-1-ol and 3,6-nonadien-1-ol detected by GC-olfactometry are responsible for the fresh and marine odors in the halophyte plant Mertensia maritima L. [50]. Oven-dried S. ramosissima is characterized by a green and herbal aroma, therefore the seaweed odor characteristic is less intensive compared to the fresh plant due to reduction of 3-hexen-1-ol [50].

The freeze-drying process is less aggressive than the oven-drying used due to the low temperature and oxygen content [65-67]. Results show that in the freeze-dried plant, there was an increase in the contribution of the terpenes class from 19.0 to $57.7 \%$ and these compounds are usually responsible for aromas described as fresh, eucalyptus, and camphoraceous. Terpenes were also the most represented volatiles in freeze-dried sea fennel (Crithmum maritimum L.), specifically limonene, $\gamma$-terpinene, $\alpha$-pinene, $p$-cymene, sabinene, myrcene, $\alpha$-thujene, camphene, $\beta$-thujene, $\alpha$-terpinene, $(Z)$ - $\beta$-ocimene, and terpinolene, which have also been identified in S. ramosissima [68]. 


\subsection{Phytochemical Characterization and Biological Activities}

\subsubsection{Identification and Quantification of Phenolic Compounds}

The phenolic compounds of the fresh, oven-dried, and freeze-dried S. ramosissima were tentatively identified by LC-DAD-ESI-MS/MS with ESI negative ionization mode. Ionization conditions in the mass spectrometer were optimized in order to detect the $\mathrm{m} / \mathrm{z}$ corresponding to the precursor ions. Table 3 shows a list of 29 compounds tentatively identified, including their retention time $\left(t_{R}\right), U V$ absorption maxima, precursor ion, the MS/MS product ions, and the bibliographic references to support the putative identification. The compounds were numbered by their elution order as most of them were not found in all plant extracts. Among the identified phenolic compounds, 15 hydroxycinnamic acids (neochlorogenic, chlorogenic, $p$-coumaric, ferulic, and caffeic glycosides acids) and nine flavonoids (quercetin glycosides and apigenin glycoside) were identified.

Some organic acids were identified in S. ramosissima extracts such as malic (peak 2) and quinic (peak 3) acids with percursor ions $[\mathrm{M}-\mathrm{H}]^{-}$at $m / z 133$ and 191, respectively, and product ions according to the literature [69,70]. Compounds 4 and 10 were identified as neochlorogenic acid (5-O-caffeoylquinic acid) and chlorogenic acid (3-O-caffeoylquinic acid), respectively. These phenolic acids are characterized by a percursor ion at $\mathrm{m} / \mathrm{z} 353$ and product ions at $m / z 191,179$, and 135 [71-73]. In this study, chlorogenic acids are distinguished due to their different retention times and the difference in product ions relative intensities. The product ions at $m / z 179$ and 135 are in general more intense in neochlorogenic acid [72,73]. In addition, the chlorogenic acid standard was analyzed and this identification was confirmed (Table 4).

Chlorogenic acid is found naturally in various plants, fruits, and vegetables such as coffee beans, apples, and blueberries, and its bioavailability depends largely on its metabolism by the gut microflora, as it is hydrolyzed into caffeic acid and quinic acid [74]. Chlorogenic acids and their derivates have health beneficial effects including neuroprotective, anti-inflammatory, cardiovascular protective, hepatoprotective, antihypertensive, glucose and lipid metabolism regulatory, and anticarcinogenic effects [12,75-77].

Caffeoylquinic dimers were also identified, such as 3,5-dicaffeoylquinic (peak 24) and 4,5-dicaffeoylquinic acids (peak 25) with a percursor ion $[\mathrm{M}-\mathrm{H}]^{-}$at $m / z 515$ and product ion characteristics of caffeoylquinic, quinic, and caffeic acids $(m / z 353,191$, and 179 , respectively) $[70,78]$. Previous studies reported antihypertensive and hypoglycemic activity for dicaffeoylquinic acids [79-81].

Flavonoids such as quercetin-3-glucoside (peak 21) and quercetin-malonyglucoside (peak 23) were identified. Quercetin 3-glucoside presented a precursor ion $[\mathrm{M}-\mathrm{H}]^{-}$at $\mathrm{m} / \mathrm{z} 463$ and a product ion at $\mathrm{m} / \mathrm{z} 301$ (aglycone quercetin), in line with the cleavage of a hexosyl residue (162 amu) [82]. Quercetin-malonyglucoside displayed a precursor ion $[\mathrm{M}-\mathrm{H}]^{-}$at $m / z 549$ and a product ion at $m / z 505$ (loss of $\mathrm{CO}_{2}, 44 \mathrm{amu}$ ), $m / z 463$ (loss of $\left.\mathrm{CH}_{2} \mathrm{O}, 42 \mathrm{amu}\right)$, and $301(162 \mathrm{amu})$, corresponding to the cleavage of a malonyhexose $(248 \mathrm{amu})[83,84]$. Quercetin glycosides are known to present antioxidant, anti-carcinogenic, antiviral, antibacterial, and anti-inflammatory activities [85,86]. 
Table 3. Phenolic compounds putatively identified in the fresh, oven-dried, and freeze-dried extracts from S. ramosissima.

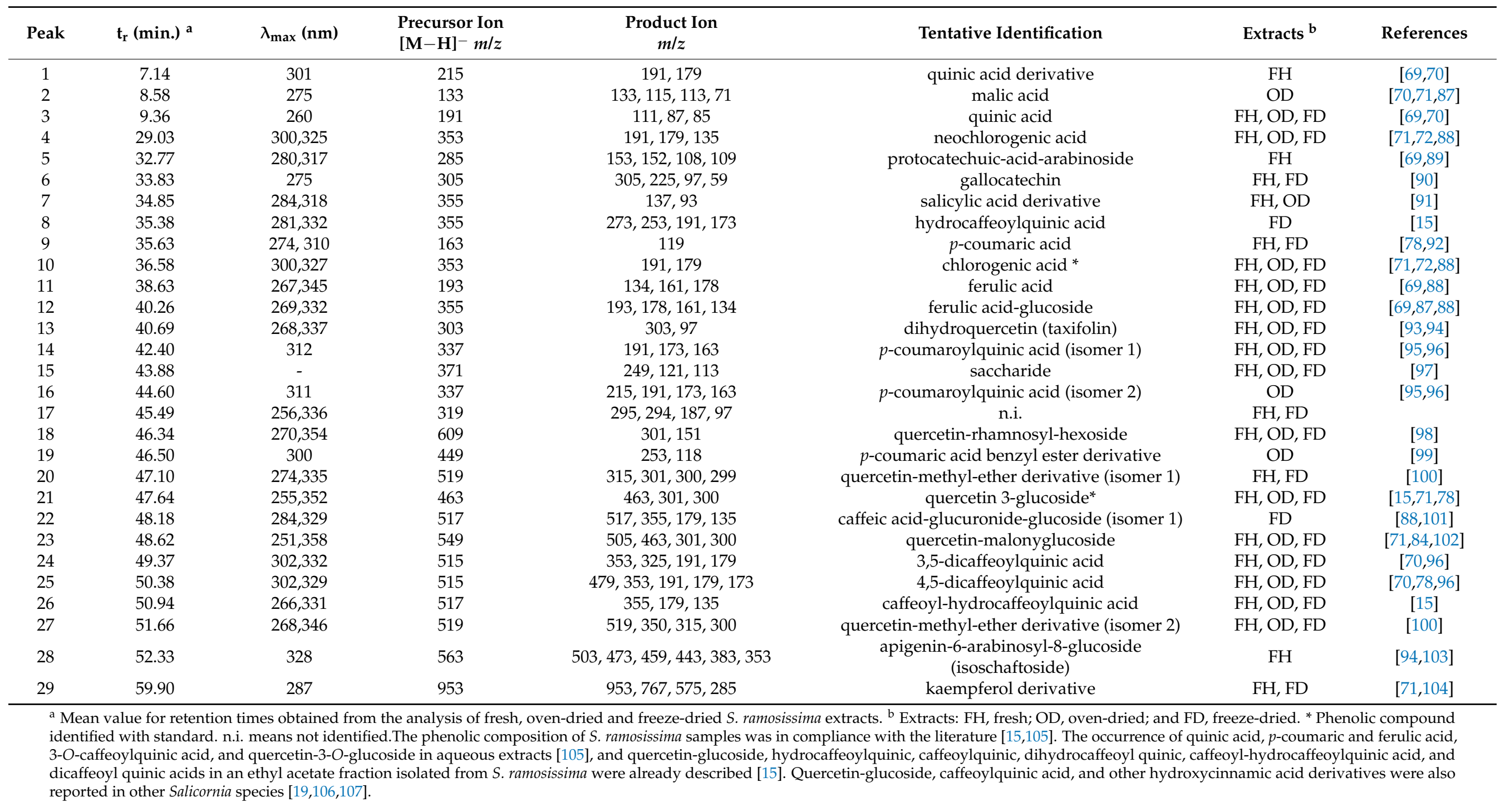


In the dried plants, it was possible to putatively identify some compounds that had not been identified in the fresh plant, such as a second isomer of $p$-coumaroylquinic acid and a $p$-coumaric acid benzyl ester derivative in the oven-dried plant, and hydrocaffeoylquinic acid and an isomer of caffeic acid-glucuronide-glucoside in the freeze-dried plant. Furthermore, quercetin 3-glucoside, quercetin-malonyhexoside, 3,5-dicaffeoylquinic acid, and 4,5-dicaffeoylquinic acid showed a higher concentration in the freeze-dried plant than in the fresh plant (Table 4) and it could be attributed to the higher extraction efficiency. The freeze-drying process is responsible for the higher porosity ( $80 \%$ to $90 \%$ ) of the freeze-dried plant material compared to the material obtained by the convective-drying method [108], increasing solvent diffusion through dried tissue, and consequently resulting in the transfer of phenolic compounds to the solvent [109].

Table 4. Quantification of phenolic compounds in the fresh, oven-dried, and freeze-dried extracts of S. ramosissima.

\begin{tabular}{|c|c|c|c|c|c|}
\hline Peak & Quantified Compounds ${ }^{a b}$ & $\begin{array}{c}\text { Fresh } \\
(\mu g / g \text { fw) }\end{array}$ & $\begin{array}{c}\text { Fresh } \\
(\mu \mathrm{g} / \mathrm{g} d w)^{c}\end{array}$ & $\begin{array}{l}\text { Oven-Dried } \\
(\mu \mathrm{g} / \mathrm{g} \mathrm{dw})\end{array}$ & $\begin{array}{l}\text { Freeze-Dried } \\
\quad(\mu \mathrm{g} / \mathrm{g} \mathrm{dw})\end{array}$ \\
\hline 3 & quinic acid $* * *$ & $9.33 \pm 2.54$ & $79.11 \pm 21.52^{B}$ & $117.4 \pm 1.28^{\mathrm{aA}}$ & $58.67 \pm 1.51 \mathrm{bB}$ \\
\hline 4 & neochlorogenic acid * & $18.03 \pm 4.40$ & $152.80 \pm 37.27^{\mathrm{A}}$ & $136.12 \pm 2.51^{\mathrm{aA}}$ & $106.81 \pm 3.06^{\mathrm{bA}}$ \\
\hline 5 & protocatechuic-arabinoside acid * & $3.00 \pm 0.10$ & $25.43 \pm 0.87$ & - & - \\
\hline 6 & gallocatechin ** & $5.25 \pm 0.78$ & $44.54 \pm 6.58^{\mathrm{a}}$ & - & $25.52 \pm 0.44^{b}$ \\
\hline 7 & salicylic acid derivative * & $2.54 \pm 0.01$ & $21.53 \pm 0.08^{a}$ & $13.74 \pm 0.30^{\mathrm{b}}$ & - \\
\hline 8 & hydrocaffeoylquinic acid * & - & - & - & $12.82 \pm 0.04$ \\
\hline 9 & $p$-coumaric acid * & $2.75 \pm 0.04$ & $23.33 \pm 0.37^{\mathrm{a}}$ & - & $19.00 \pm 0.26^{\mathrm{a}}$ \\
\hline 10 & chlorogenic acid * & $53.19 \pm 13.59$ & $450.76 \pm 115.17^{\mathrm{A}}$ & $318.74 \pm 11.11^{\mathrm{bA}}$ & $421.91 \pm 13.08^{\mathrm{aA}}$ \\
\hline 11 & ferulic acid * & $4.21 \pm 0.40$ & $35.72 \pm 3.38^{\mathrm{A}}$ & $24.01 \pm 0.13^{\mathrm{bB}}$ & $26.58 \pm 0.39 \mathrm{aB}$ \\
\hline 12 & ferulic-glucoside acid * & $5.98 \pm 0.40$ & $50.69 \pm 3.36^{\mathrm{A}}$ & $21.23 \pm 9.35^{\mathrm{aB}}$ & $46.92 \pm 2.15^{\mathrm{aA}}$ \\
\hline 13 & dihydroquercetin ** & $2.86 \pm 0.08$ & $24.21 \pm 0.65^{\mathrm{A}}$ & $18.58 \pm 1.62^{\mathrm{aB}}$ & $14.52 \pm 0.13^{\mathrm{aB}}$ \\
\hline 14 & $\begin{array}{l}p \text {-coumaroylquinic acid } \\
\quad(\text { isomer } 1)^{*}\end{array}$ & $2.72 \pm 0.09$ & $2.08 \pm 0.74^{\mathrm{A}}$ & $15.48 \pm 0.06^{\mathrm{aB}}$ & $13.77 \pm 0.04^{\mathrm{bB}}$ \\
\hline 16 & $\begin{array}{l}p \text {-coumaroylquinic acid } \\
\text { (isomer } 2) *\end{array}$ & - & - & $24.63 \pm 0.74$ & - \\
\hline 18 & quercetin-rhamnosyl-hexoside ** & $7.65 \pm 1.13$ & $64.81 \pm 9.62^{\mathrm{A}}$ & $52.90 \pm 1.34 \mathrm{bA}$ & $74.49 \pm 2.31^{\mathrm{aA}}$ \\
\hline 19 & $\begin{array}{c}p \text {-coumaric acid benzyl ester } \\
\text { derivative * }\end{array}$ & - & - & $72.51 \pm 2.22$ & - \\
\hline 20 & $\begin{array}{l}\text { quercetin-methyl-ether derivative } \\
\text { (isomer } 1)^{* *}\end{array}$ & $13.60 \pm 1.09$ & $115.26 \pm 9.20^{a}$ & - & $35.21 \pm 22.13^{b}$ \\
\hline 21 & $\begin{array}{c}\text { quercetin 3-glucoside }{ }^{* *} \\
\text { caffeic }\end{array}$ & $53.53 \pm 8.11$ & $453.66 \pm 68.76^{B}$ & $688.38 \pm 16.48^{\mathrm{aA}}$ & $636.02 \pm 19.47^{\mathrm{aA}}$ \\
\hline 22 & $\begin{array}{l}\text { acid-glucuronide-glucoside } \\
\text { (isomer 1)* }\end{array}$ & - & - & - & $53.40 \pm 1.64$ \\
\hline 23 & quercetin-malonyglucoside ** & $309.39 \pm 60.74$ & $2621.99 \pm 514.72^{B}$ & $1578.0 \pm 30.0 \mathrm{bB}$ & $4202.52 \pm 48.09 \mathrm{aA}$ \\
\hline 24 & 3,5-dicaffeoylquinic acid * & $25.83 \pm 0.05$ & $218.87 \pm 0.40^{\mathrm{B}}$ & $223.38 \pm 9.27^{b B}$ & $434.88 \pm 13.95^{\mathrm{aA}}$ \\
\hline 25 & 4,5-dicaffeoylquinic acid * & $11.75 \pm 0.533$ & $99.58 \pm 4.52^{\text {В }}$ & $223.22 \pm 9.67^{\mathrm{aA}}$ & $213.09 \pm 5.97^{\mathrm{aA}}$ \\
\hline 26 & $\begin{array}{l}\text { caffeoyl-hydrocaffeoylquinic } \\
\text { acid * }\end{array}$ & $9.72 \pm 3.13$ & $82.40 \pm 26.59^{B}$ & $138.67 \pm 7.37^{\mathrm{aAB}}$ & $163.14 \pm 4.64^{\mathrm{aA}}$ \\
\hline 27 & $\begin{array}{l}\text { quercetin-methyl-ether derivative } \\
\text { (isomer } 2)^{* *}\end{array}$ & $13.36 \pm 2.70$ & $113.23 \pm 22.91^{\mathrm{A}}$ & $56.11 \pm 1.43^{\mathrm{bB}}$ & $101.18 \pm 2.26^{\mathrm{aAB}}$ \\
\hline 28 & $\begin{array}{l}\text { apigenin-6-arabinosyl-8- } \\
\text { glucoside } \\
\text { (isoschaftoside) }^{* *}\end{array}$ & $3.82 \pm 0.11$ & $32.38 \pm 0.96$ & - & - \\
\hline \multirow[t]{3}{*}{29} & kaempferol derivative ${ }^{* *}$ & $10.90 \pm 2.09$ & $92.42 \pm 17.71^{\mathrm{a}}$ & - & $62.19 \pm 1.75^{b}$ \\
\hline & Total Flavonoids & 420.36 & 3562.50 & 2393.97 & 5151.65 \\
\hline & Total Hydroxycinnamic & 139.72 & 1163.19 & 1211.73 & 1512.32 \\
\hline
\end{tabular}

${ }^{\mathrm{a}}$ Data are expressed as means values \pm standard deviation $(n=2) .{ }^{\mathrm{b}}$ The lower-case letters $(\mathrm{a}$ and $\mathrm{b})$ correspond to the significant difference by the unpaired $t$-test $(p<0.05)$. The upper-case letters $(\mathrm{A}, \mathrm{B})$ indicate the significant differences by Tukey's test $(p<0.05) .{ }^{\mathrm{c}}$ The values were converted from fresh weight to dried weight according to the moisture value. Phenolic compounds were identified with standard. $\left({ }^{*}\right)$ Chlorogenic acid and derivatives were quantified as a chlorogenic acid equivalent. $\left({ }^{* *}\right)$ Quercetin-3-glucose and quercetin glycosylated derivatives were quantified as a quercetin-3-glucose equivalent. (**) Quinic acid was quantified as a gallic acid equivalent. 
Despite the freeze-drying process generating a significant increase in the amount of dicaffeoylquinic acids and quercetin glucosides compared to the fresh plant $(\mu \mathrm{g} / \mathrm{g} \mathrm{dw})$, for protocatechuic-arabinoside acid, ferulic acid, dihydroquercetin, $p$-coumaroylquinic acid (isomer 1), a quercetin-methyl-ether derivative, and a kaempferol derivative, a decrease was observed, as shown in Table 4. This effect may be related to oxidation, the most important biochemical process that occurs during the processing of the plants, which starts as soon as the integrity of the cell is broken [110], namely during the grinding process for sample preparation. The total flavonoids and total hydroxycinnamic acids in the freezedried plant were $5151.65 \mu \mathrm{g} / \mathrm{g} \mathrm{dw}$ and $1512.32 \mu \mathrm{g} / \mathrm{g} \mathrm{dw}$, while in the oven-dried plant they were lower $(2393.97 \mu \mathrm{g} / \mathrm{g} \mathrm{dw}$ and $1211.73 \mu \mathrm{g} / \mathrm{g} \mathrm{dw}$, respectively), as can be seen in Table 4 . These results show that the oven-drying process generated a reduction of $54 \%$ in the total flavonoids and $20 \%$ in the total hydroxycinnamic acids compared to freeze-dried plant.

Similar to our results, studies $[80,111,112]$ have showed that the freeze-drying process preserves the bioactive compounds and retains a higher amount of polyphenols in herbs, while the oven-drying process causes major loss of these compounds, especially with drying temperatures higher than $60^{\circ} \mathrm{C}$. The freeze-drying process is able to preserve the polyphenol content as it prevents its thermal and oxidative degradation, and limits enzymatic reactions from polyphenol oxidase, lipoxygenase, and peroxidase [113-115]. Oven-drying methods have demonstrated to have a significant impact on the flavonoid content. Flavonoids are negatively affected by hot air-drying, which are degraded proportionally to an increase in the temperature $[113,116]$.

In general, the results show that the oven-drying process affects the phenolic composition, reducing the quercetin glycosides, but the chlorogenic acids and their derivatives are minimally affected. In terms of phenolic composition, the freeze-drying method is less aggressive than the oven-drying method.

\subsubsection{Bioactivity: Antioxidant, Antihypertensive, and Antiproliferative Effects}

As mentioned above, the drying method is considered the most common technique for the postharvest preservation of herbs and edible plants; however, this technique is reported to have an influence on the content of bioactive compounds in several food matrices [112], including $S$. ramosissima. In Table 5, the impact of the drying process on the total phenolic content (TPC) and bioactivity of $S$. ramossima, namely antioxidant and antihypertensive activities, is described.

Table 5. Total phenolic content and both antioxidant and antihypertensive activities of extracts from the fresh, oven-dried, and freeze-dried S. ramosissima.

\begin{tabular}{|c|c|c|c|c|}
\hline Processing Plant & $\begin{array}{l}\text { Fresh } \\
(f w)^{a}\end{array}$ & $\begin{array}{l}\text { Fresh } \\
(\mathrm{dw})^{\mathrm{abc}}\end{array}$ & $\begin{array}{l}\text { Oven-Dried } \\
\quad(d w)^{a b}\end{array}$ & $\begin{array}{l}\text { Freeze-Dried } \\
\qquad(\mathrm{dw})^{\mathrm{ab}}\end{array}$ \\
\hline TPC (mg GAE/g) & $1.02 \pm 0.04$ & $8.64 \pm 0.34^{\mathrm{A}}$ & $7.41 \pm 0.29 \mathrm{bB}$ & $9.74 \pm 0.88^{\mathrm{aA}}$ \\
\hline $\begin{array}{c}\text { Antioxidant activity } \\
\text { ORAC ( } \mu \mathrm{mol} \text { TEAC/g) } \\
\text { HOSC }(\mu \mathrm{mol} \text { TEAC/g) }\end{array}$ & $\begin{array}{l}23.85 \pm 3.04 \\
26.06 \pm 2.29\end{array}$ & $\begin{array}{l}202.10 \pm 25.81^{\mathrm{B}} \\
220.21 \pm 15.51^{\mathrm{A}}\end{array}$ & $\begin{array}{l}291.10 \pm 17.95^{\mathrm{bB}} \\
147.21 \pm 12.44^{\mathrm{bB}}\end{array}$ & $\begin{array}{l}418.81 \pm 54.01^{\mathrm{aA}} \\
237.20 \pm 12.02^{\mathrm{aA}}\end{array}$ \\
\hline $\begin{array}{c}\text { Antihypertensive activity } \\
\text { ACE inhibition }\left(\mathrm{IC}_{50}=\mathrm{mg} / \mathrm{mL}\right)\end{array}$ & $95.61 \pm 14.13$ & $12.60 \pm 1.73^{\mathrm{A}}$ & $24.56 \pm 1.74^{\mathrm{aB}}$ & $18.96 \pm 0.62^{\mathrm{aB}}$ \\
\hline
\end{tabular}

${ }^{a}$ Data are expressed as means values \pm standard deviation $(n=3) .{ }^{b}$ The lower-case letters $(a$ and $b)$ correspond to the statistical analysis performed to calculate the existence of a significant difference $(p<0.05)$ between both drying methods by the unpaired $t$-test. The upper-case letters $(\mathrm{A}, \mathrm{B})$ correspond to the statistical analysis performed to calculate the existence of a significant difference $(p<0.05)$ by Tukey's test. ${ }^{c}$ The values were converted from fresh weight to dried weight according to the moisture value.

The TPC value of fresh S. ramosissima was $1.02 \mathrm{mg} \mathrm{GAE} / \mathrm{g} \mathrm{fw}$ and these values are in the same range as previously described for fresh Salicornia genus, between 1.05 and $1.53 \mathrm{mg} \mathrm{GAE} / \mathrm{g} \mathrm{fw}$ [43]. This value is above the lower limit of other condiments rated as rich in phenolic compounds ( $<1.0 \mathrm{mg} \mathrm{GAE} / \mathrm{g} \mathrm{fw})$, such as celery (0.31), garlic (1.01), onion yellow (0.95), capsicum green (0.59), leek (0.85) [117], and coriander (0.60) [118]. 
Results showed that a lower TPC value was observed in the oven-dried extract (7.41 mg GAE/g) than in the fresh and freeze-dried plant extract (8.64 and $9.74 \mathrm{mg} \mathrm{GAE} / \mathrm{g} \mathrm{dw}$, respectively). The TPC values from the freeze-dried extract are also in accordance to data already reported (7.03 to $12.09 \mathrm{mg} \mathrm{GAE} / \mathrm{g} \mathrm{dw}$ ) [10] and values for other species of freezedried Salicornia, namely Salicornia europaea (5.6 to $9.30 \mathrm{mg}$ GAE/g dw) [119]. In contrast, studies on oven-dried $S$. ramosissima reported higher TPC values than the one reported in this work (27.44 to $33.00 \mathrm{mg} \mathrm{GAE} / \mathrm{g} \mathrm{dw}$ ) [7,15]. This difference can be due to several factors related to the culture conditions of the fresh plant including the salt stress conditions and environmental changes $[10,36]$. Halophytes live in extremely harsh environments with high salinities and UV radiation, and these stressful conditions lead to the production of secondary metabolites such as the phenolic compounds in different concentrations [7].

The phenolic content of dried plants has high positive significant correlations with their antioxidant activity (average $r>0.9741$ ). Correlation between the TPC and ORAC assay was 0.985 , while between TPC and HOSC was 0.962 . The freeze-drying plant presented a significantly higher value of the ORAC compared to the fresh plant $(202.10 \mu \mathrm{mol}$ TEAC $/ \mathrm{g} \mathrm{dw})$ and a similar value in the HOSC assay $(220.21 \mu \mathrm{mol}$ TEAC/g dw). This result can be explained by the highest concentrations observed of the flavonoids in the freeze-dried plant [120]. Flavonoids are generally more capable of inactivating peroxyl radicals than the small phenolic antioxidants, whereas hydroxycinnamic acids are very effective in the inactivation of hydroxyl radicals [121].

This study showed that there are differences among the drying processes, which can be explained by the reduction of the phenolic profile of the oven-dried plant compared to freeze-dried (Table 4). The oven-drying process presented an average reduction of $31 \%$ in antioxidant activity probably due to the reduction of quercetin glycosides. The reactions involved in the decrease of phenolics compounds with increasing drying temperature $\left(40-70{ }^{\circ} \mathrm{C}\right)$ are associated to enzymatic and non-enzymatic oxidation reactions [21,122]. Similarly to our results, studies also showed that the oven-drying process of $S$. fruticosa exposed to a high temperature $\left(70^{\circ} \mathrm{C}\right)$ for a long time contributed to the reduction of the polyphenols content [21] and the loss of antioxidant properties [48].

The antihypertensive activity of $S$. ramosissima samples was evaluated through of the ACE inhibition assay. The ACE inhibitors are commonly used in therapy for the treatment of hypertension and cardiovascular diseases $[123,124]$. $\mathrm{IC}_{50}$ values obtained for the dried plants were significantly different from the $\mathrm{IC}_{50}$ value of the fresh plant. However, $\mathrm{IC}_{50}$ values of dried plants did not show significant differences between them, indicating that the oven-drying process does not have a significant impact on the compounds that are responsible for the inhibition of the ACE enzyme.

In the same manner, both dried plants demonstrated similar antiproliferative effects in colorectal cancer cells (HT29) (Figure 3). Fresh and dried extracts had the ability to impair HT29 cell proliferation in a dose-dependent manner (Figure 3a-c), with an $\mathrm{EC}_{50}$ value of $15.82 \mathrm{mg} / \mathrm{mL} \mathrm{dw}, 17.56 \mathrm{mg} / \mathrm{mL}$, and $17.24 \mathrm{mg} / \mathrm{mL}$ for the fresh, oven-dried and freeze-dried plants, respectively (Figure 3d). It is important to mention that the $\mathrm{EC}_{50}$ values determined in this work did not present cytotoxic effects in confluent Caco-2 cells, a cell model widely used to evaluate the effect of chemicals and food bioactive compounds in intestinal function.

The similar bioactive response in terms of the antiproliferative and anti-hyperglycemic effects among both drying samples could be attributed to their similar composition in bioactive compounds, namely quercetin-3-O-glucoside, neochlorogenic acid, ferulic acidglucoside, caffeic acid-glucuronide-glucoside, and 3,5-dicaffeoylquinic acid (Table 4). Accordingly, it has been reported that quercetin glycosides have a significant impact on ACE inhibition, in which quercetin-3-O-glucoside is the most effective ACE inhibitor among the flavonoids' glycosides $[125,126]$. Quercetin glucosides also have an antiproliferative activity in human cancer cells with inhibitory effects on proliferation of HT29 cells [14,127]. Similarly, caffeoylquinic acids are able to reduce HT29 cell viability, promoting specific 
changes in the cell cycle, and increase the apoptosis rate $[11,128,129]$, and their derivatives are found to be effective as natural ACE inhibitors [126,130,131].

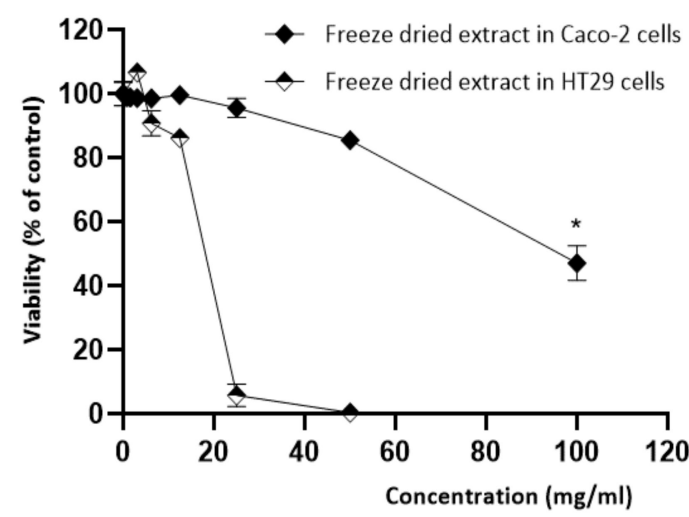

(a)

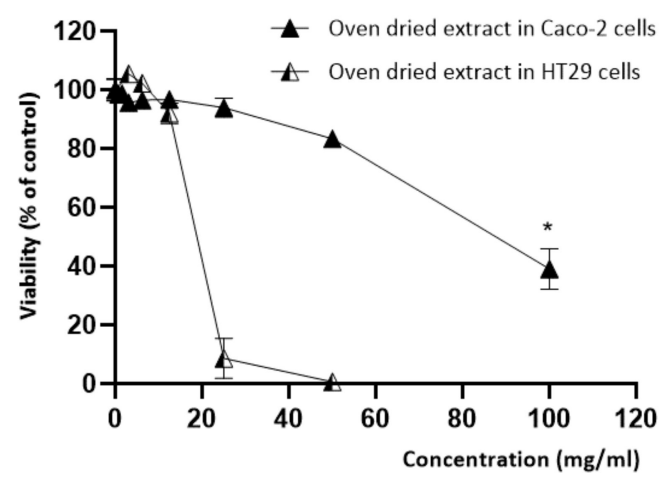

(c)

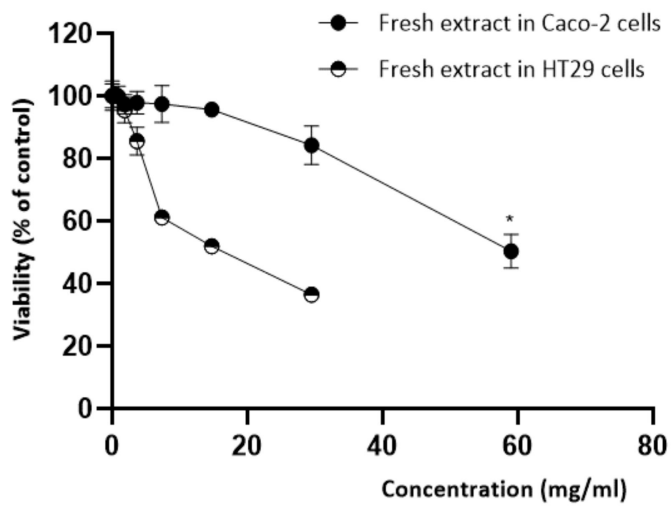

(b)

Antiproliferative effect

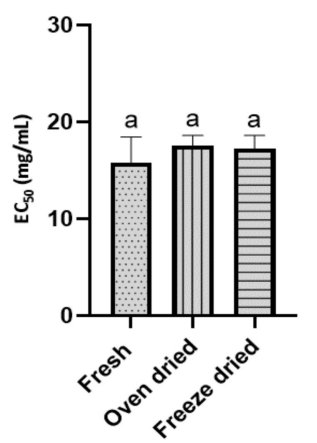

(d)

Figure 3. Fresh, oven-dried, and freeze-dried extracts from S. ramosissima exerted antiproliferative effects in a dosedependent manner after exposition for $24 \mathrm{~h}$. Dose-response curves of the antiproliferative effect induced by the (a) freeze-dried extract, (b) oven-dried extract, and (c) fresh extract. (d) $\mathrm{EC}_{50}$ values of the antiproliferative response induced by the fresh $\left(\mathrm{EC}_{50}=15.82 \pm 2.65 \mathrm{mg} / \mathrm{mL}\right)$, oven-dried $\left(\mathrm{EC}_{50}=17.56 \pm 1.05 \mathrm{mg} / \mathrm{mL}\right)$, and freeze-dried $\left(E_{50}=17.24 \pm 1.36 \mathrm{mg} / \mathrm{mL}\right.$ ) extracts in HT29 cells (cell model of CRC) did not show significant differences. Results shown are means of at least three independent experiments performed in triplicates \pm SD. ${ }^{*}$ ) represent the existence of statistical difference between that dose and the previous one, using one-way ANOVA for multiple comparisons by Tukey's test $(p<0.05)$.

In addition, the synergistic effects between quercetin glycosides and caffeoylquinic acids in the dried extracts from $S$. ramosissima may also have contributed to similar antihypertensive and antiproliferative activities. Phenolic extracts from halophyte plants and their isolated polyphenols have been studied in a number of cancer cell lines and antihypertensive models [132-136]. Extracts from halophytes, such as Salicornia herbacea seed cells, showed potent antioxidant activity and selective cytotoxic effects against HT29 and HCT116 human colon adenocarcinoma [132]. In addition, Artemisia scoparia, Cocos nucifera, and Tribulus terrestris showed ACE inhibitory activity [135-139].

\subsection{Sensorial Analysis: Consumer Acceptance of Oven-Dried S. ramosissima}

Aimed at evaluating the acceptance of $S$. ramosissima as a natural salt substitute, a sensory test with a ketchup formulated with dried S. ramosissima at $2.2 \%$ (sample $2.2 \%$ DS) and $3.0 \%$ w/w (sample 3.0\% DS) was carried out with 102 volunteers (69\% women and 31\% men, aged between 29 and 59 years old). The information obtained in the questionnaires about each consumer is shown in Supplementary Materials Table S1. For this experiment, the oven-dried plant was selected as it presents several advantages over the freeze-dried 
sample, including (i) the reduction of alcohols, which could impact the consumer acceptability due to the association with marine odor, and (ii) low processing costs, which is more attractive to food industry applications. Additionally, this sample also showed similar bioactive effects as the freeze-dried plant, indicating that the lower phenolic composition did not impact its antiproliferative and antihypertensive potential.

Consumers evaluated the sensory characteristics of the two ketchups, including appearance, aroma, flavor, and overall liking. The mean scores for the ketchup sensory attributes are presented in Figure 4.

Consumer acceptability scores for overall liking, aroma, and flavor were significantly different $(p>0.05)$ across the two ketchup formulations as the sample $2.2 \%$ DS showed higher consumer acceptability compared to sample $3.0 \%$ DS. In contrast, the consumer acceptability scores for appearance were not significantly different between the two ketchups. The results of the evaluation indicate a good consumer acceptance for the ketchup with the lower addition of the oven-dried S. ramosissima (sample $2.2 \%$ DS) and, consequently, a product with less salt content ( $0.91 \%$ of salt) (see Supplementary Materials Table S2). Although the consumption of ketchup is mostly associated with unhealthy eating, the addition of the dried S. ramosissima as a table salt substitute in ketchup becomes a potential ingredient to be considered, which can be applied for the development of low sodium products.

\section{Acceptability testing}

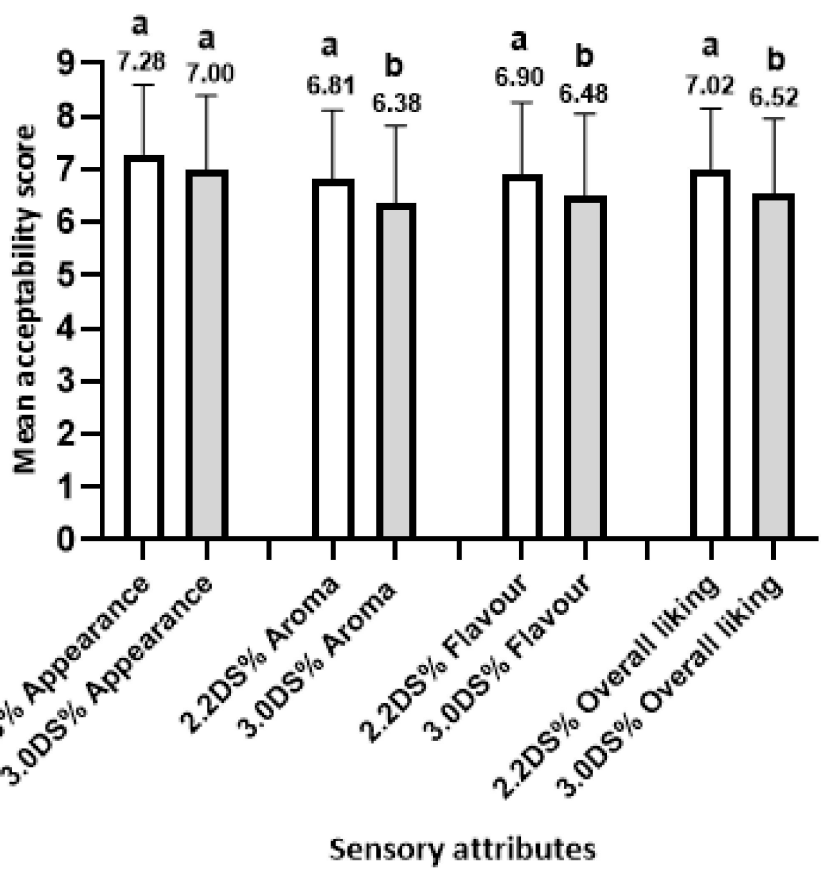

Figure 4. Evaluation mean scores for sensory attributes of the ketchups with $2.2 \%$ oven-dried S. ramosissima (2.2DS\%) and 3.0\% oven-dried S. ramosissima (3.0DS $\%$ ) ( $n=102$ consumers). Each sensory attribute was evaluated using a nine-point hedonic scale where 1 = "disliked extremely" and $9=$ "liked extremely". The letters ( $a$ and b) correspond to the statistical analysis performed to calculate the existence of a significant difference $(p<0.05)$ between each sample according to the unpaired $t$-test.

\section{Conclusions}

This study contributed by evaluating the effect of two drying processes in the preservation of the nutritional composition and bioactive compounds present in S. ramosissima. The results generated herein demostrated that both drying processes, namely oven-drying and freeze-drying, have an impact on the nutritional composition of S. ramosissima, as well 
as in the phytochemical content and antioxidant capacity, which are significantly reduced during the oven-drying of the plant compared to the freeze-drying process. Neverthless, antiproliferative and antihypertensive activities of the dried plants are not dependent on the type of drying process, meaning that other compounds present in theses plants may be more important for these activities.

During the oven-dried process, the volatile composition was also affected, leading to a decrease of compounds such as alcohols. Some of these compounds have been associated with marine odors and may affect the consumer acceptability of food products formulated with $S$. ramosissima as a natural ingredient.

These results indicate that the dried S. ramosissima could be an adequate option for use in the food and gourmet cuisine industry to replace table salt, even in the dried form, as they can have high amounts of $\mathrm{NaCl}$ and also phytochemicals that are important for their contribution in the prevention of diseases. The extracts from the analyzed plants also demonstrate potencial bioactivity and more research should be done concerning not only the other phytochemicals that may be present in these plants, but also the study of the amounts of plants that should be used in order be a salt substitute ingredient in a healthy diet.

Supplementary Materials: The following are available online at https:/ /www.mdpi.com/article/10 .3390/antiox10081312/s1.

Author Contributions: Conceptualization, S.C.O.-A., A.T.S. and M.R.B.; methodology, S.C.O.-A., F.A., I.P., A.B.S., J.C. (Jorge Capelo), B.D. and I.C.; formal analysis, S.C.O.-A., F.A., I.P. and A.B.S.; investigation, S.C.O.-A., F.A., A.B.S., B.D., J.C. (Júlio Coelho) and I.C.; data curation, S.C.O.-A. and F.A.; writing-original draft preparation, S.C.O.-A. and F.A.; writing-review and editing, S.C.O.-A., F.A., I.P., B.D., I.C., A.T.S. and M.R.B.; supervision, S.C.O.-A., A.T.S. and M.R.B.; project administration, S.C.O.-A., A.T.S. and M.R.B.; funding acquisition, A.T.S. and M.R.B. All authors have read and agreed to the published version of the manuscript.

Funding: This study was funded by (i) iNOVA4Health, UIDB/04462/2020 and UIDP/04462/2020, a program financially supported by Fundação para a Ciência e Tecnologia/Ministério da Ciência, Tecnologia e Ensino Superior through national funds; (ii) the INTERFACE Programme through the Innovation, Technology, and Circular Economy Fund (FITEC); and (iii) the Portuguese Mass Spectrometry Network (Rede Nacional de Espectrometria de Massa - RNEM; LISBOA-01-0145FEDER-402- 022125).

Institutional Review Board Statement: Not applicable.

Informed Consent Statement: Not applicable.

Data Availability Statement: The data supporting the findings of this study are available within the article and its Supplementary Materials.

Acknowledgments: The authors acknowledge Mendes Goncalves SA. for the development of the ketchup samples for the sensorial analysis. Authors are also grateful to Martim Cardeira and Agostinho Alexandre from iBET for their technical assistance with the freeze-drying process and sensorial analysis. A.T.S. also thanks Fundação para a Ciência e Tecnologia/ Ministério da Ciência, Tecnologia e Ensino Superior for the individual grant CEECIND/04801/2017.

Conflicts of Interest: The authors declare no conflict of interest. 
Appendix A

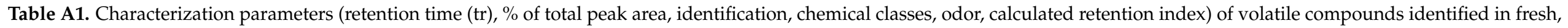
oven dried and freeze dried S. ramosissima using SPME-GC-MS and the bibliographic references to support the identification.

\begin{tabular}{|c|c|c|c|c|c|c|c|c|c|c|}
\hline Peak & $t_{r}(\min .)^{a}$ & $\begin{array}{l}\text { Area } \% \\
\text { Fresh }\end{array}$ & $\begin{array}{c}\text { Area \% } \\
\text { oven } \\
\text { Dried }\end{array}$ & $\begin{array}{c}\text { Area \% } \\
\text { Freeze } \\
\text { Dried }\end{array}$ & Compounds & $\begin{array}{l}\text { Chemical } \\
\text { Classes }\end{array}$ & Odor Description ${ }^{b}$ & $\begin{array}{l}\text { Calc. } \\
\text { LRI }^{c}\end{array}$ & Lit. LRI & References \\
\hline 1 & 5.012 & 0.26 & 34.16 & 1.30 & hexanal & Aldehyde & herbal, grassy, green & 800 & 801 & {$[35,50,140,141]$} \\
\hline 2 & 6.700 & 0.46 & - & - & 1-methoxy-3-hexene & Hydrocarbon & not found & 847 & 826 & [142] \\
\hline 3 & 6.962 & - & - & 0.68 & 2-hexenal & Aldehyde & floral, herbal & 853 & 850 & {$[140,141]$} \\
\hline 4 & 7.103 & 47.95 & 1.80 & - & 3-hexen-1-ol & Alcohol & green, marine, seaweed & 857 & 852 & {$[50,52,143]$} \\
\hline 5 & 7.635 & - & - & 0.04 & 3-methyl-1-pentanol & Alcohol & fruity, floral & 871 & 852 & {$[144,145]$} \\
\hline 6 & 7.653 & 47.82 & - & - & 1-hexanol & Alcohol & woody, sweet, green, fruity & 867 & 872 & {$[53,141,146]$} \\
\hline 8 & 8.722 & - & 5.14 & 0.10 & heptanal & Aldehyde & penetrating oily, harsh & 901 & 902 & {$[35,53,147]$} \\
\hline 9 & 9.079 & - & 1.29 & - & butyrolactone & Lactone & cheesy, burnt sugar; buttery & 911 & 915 & {$[53,146-148]$} \\
\hline 10 & 9.278 & - & 0.17 & - & 2-3-dimethylpyrazine & Pyrazine & nutty, cocoa-like & 916 & 918 & {$[53,149]$} \\
\hline 11 & 9.569 & - & - & 0.05 & alpha-thujene & Terpene & herbal, green, weak earthy & 924 & 924 & {$[60,150,151]$} \\
\hline 12 & 9.786 & - & - & 0.88 & alpha-pinene & Terpene & oily, green & 930 & 933 & {$[58,151]$} \\
\hline 13 & 10.260 & 1.51 & - & - & ethyl tiglate & Ester & fruity & 943 & 939 & [152] \\
\hline 14 & 10.274 & - & - & 1.09 & camphene & Terpene & sweet & 943 & 947 & {$[58,151,153]$} \\
\hline 15 & 10.616 & - & 0.25 & - & $\gamma$-valerolactone & Lactone & sweet, herbaceous & 953 & 950 & {$[154,155]$} \\
\hline 16 & 10.792 & - & 1.39 & - & benzaldehyde & Aldehyde & hazelnut, roasty & 958 & 962 & {$[156,157]$} \\
\hline 19 & 11.637 & - & 3.00 & 0.01 & 1-octen-3-ol & Alcohol & mushroom & 981 & 980 & {$[50,56,150]$} \\
\hline 20 & 11.848 & - & 3.92 & 0.05 & 6-methyl-5-hepten-2-one & Ketone & banana-like & 987 & 988 & {$[143,160]$} \\
\hline 21 & 11.973 & 0.00 & 0.00 & 2.26 & beta-myrcene & Terpene & herbaceous, sweet & 990 & 991 & {$[58,150,151]$} \\
\hline 22 & 12.004 & 0.07 & 1.14 & - & 2-pentylfuran & Furan & floral, fruit & 991 & 990 & {$[154,161]$} \\
\hline 23 & 12.164 & 0.07 & 0.60 & - & hexanoic acid & $\begin{array}{l}\text { Carboxylic } \\
\text { acid }\end{array}$ & $\begin{array}{l}\text { unpleasant, rancing, } \\
\text { metallic }\end{array}$ & 995 & 993 & {$[162,163]$} \\
\hline 24 & 12.321 & - & 0.99 & - & decane & Hydrocarbon & gasoline-like, fishy & 1000 & 1000 & {$[164,165]$} \\
\hline 25 & 12.329 & - & - & 8.45 & alpha-phellandrene & Terpene & fresh, green & 1000 & 1005 & {$[59,146,153]$} \\
\hline 26 & 12.372 & - & 0.16 & - & octanal & Aldehyde & fruity, green, citrus & 1001 & 1005 & {$[146,159,166]$} \\
\hline 27 & 12.663 & 0.33 & - & - & 3-hexen-1-ol acetate & Ester & fruity, floral & 1010 & 1007 & {$[140,141]$} \\
\hline 28 & 12.793 & - & - & 0.24 & alpha-terpinene & Terpene & resinous & 1014 & 1017 & {$[59,150]$} \\
\hline 29 & 12.834 & - & 0.39 & - & 2-methylpentyl formate & Ester & not found & 1015 & - & \\
\hline 30 & 12.917 & 0.11 & - & - & hexyl acetate & Ester & fruit, herb & 1017 & 1019 & {$[145,167]$} \\
\hline
\end{tabular}


Table A1. Cont.

\begin{tabular}{|c|c|c|c|c|c|c|c|c|c|c|}
\hline Peak & $t_{r}(\min .)^{a}$ & $\begin{array}{c}\text { Area\% } \\
\text { Fresh }\end{array}$ & $\begin{array}{c}\text { Area \% } \\
\text { oven } \\
\text { Dried }\end{array}$ & $\begin{array}{c}\text { Area \% } \\
\text { Freeze } \\
\text { Dried }\end{array}$ & Compounds & $\begin{array}{l}\text { Chemical } \\
\text { Classes }\end{array}$ & Odor Description ${ }^{b}$ & $\begin{array}{l}\text { Calc. } \\
\text { LRI }^{c}\end{array}$ & Lit. LRI & References \\
\hline 31 & 13.083 & 0.02 & 3.08 & 8.80 & p-cymene & Terpene & green, fruity, aromatic & 1022 & 1027 & {$[58,158,168]$} \\
\hline 33 & 13.306 & - & - & 38.73 & 1,8-cineole & Terpene & eucalyptus, spicy, pepper & 1029 & 1032 & {$[57,156,169]$} \\
\hline 34 & 13.353 & & 1.14 & - & 2-ethyl-1-hexanol & Alcohol & $\begin{array}{l}\text { green, flowery, green } \\
\text { cucumber }\end{array}$ & 1031 & 1029 & {$[141,163,170]$} \\
\hline 35 & 13.517 & 0.08 & - & - & 2-hexenoic acid & $\begin{array}{l}\text { Carboxylic } \\
\text { acid }\end{array}$ & not found & 1035 & - & \\
\hline 36 & 13.643 & - & 0.29 & - & 3-octen-2-one & Ketone & rose & 1039 & 1040 & {$[161,171,172]$} \\
\hline 37 & 13.719 & - & 0.16 & - & phenylacetaldehyde & Aldehyde & lilac, flora & 1041 & 1043 & {$[55,156]$} \\
\hline 38 & 13.808 & 0.06 & - & - & benzyl alcohol & Alcohol & floral, fruity, rose & 1044 & 1045 & [173] \\
\hline 39 & 14.225 & - & - & 0.29 & gamma-terpinene & Terpene & green, woody & 1057 & 1059 & {$[55,58,172]$} \\
\hline 40 & 14.502 & - & - & 0.13 & trans-sabinene hydrate & Terpene & spicy, weak fruity & 1065 & 1060 & {$[60,150]$} \\
\hline 41 & 14.731 & - & 1.19 & 0.04 & 3,5-octadien-2-one & Ketone & green, marine, grass, fatty & 1072 & 1098 & {$[50,56]$} \\
\hline 42 & 15.194 & - & - & 0.37 & alpha-terpinolene & Terpene & woody, herbaceous & 1086 & 1086 & {$[55,59,107]$} \\
\hline 43 & 15.503 & - & 0.30 & - & linalool oxide & Terpene & woody & 1095 & 1092 & {$[168,174]$} \\
\hline 44 & 15.508 & 0.54 & - & - & methyl benzoate & Ester & eucalyptus, phenolic, wood & 1095 & 1094 & {$[175,176]$} \\
\hline 46 & 15.640 & - & 0.14 & - & 2,6,11-trimethyldodecane & Hydrocarbon & not found & 1099 & 1102 & [177] \\
\hline 47 & 15.724 & - & - & 7.21 & beta-thujone & Terpene & camphoraceous-herbal & 1102 & 1119 & [60] \\
\hline 48 & 15.789 & - & 7.31 & - & 3,4-dimethylcyclohexanol & Alcohol & not found & 1104 & 1103 & [178] \\
\hline 49 & 16.069 & - & - & 2.31 & alpha-thujone & Terpene & warm-herbal, minty & 1113 & 1114 & {$[60,179]$} \\
\hline 50 & 16.165 & - & 0.09 & - & $\begin{array}{l}\text { 4-hexen-1-ol, } \\
\text { 2-ethenyl-2,5-dimethyl- }\end{array}$ & Alcohol & not found & 1116 & - & \\
\hline 51 & 16.233 & 0.11 & - & - & phenylethyl alcohol & Alcohol & $\begin{array}{l}\text { sweet, perfume, floral, bee } \\
\text { wax }\end{array}$ & 1118 & 1117 & {$[50,143]$} \\
\hline 52 & 16.566 & - & - & 0.14 & 1,3,8-p-menthatriene & Terpene & green, cucumber, floral & 1129 & 1130 & {$[56,144]$} \\
\hline 53 & 16.903 & - & - & 4.80 & camphor & Terpene & camphoraceous, fresh & 1140 & 1141 & {$[55,60]$} \\
\hline 54 & 17.429 & - & - & 0.08 & trans-pinocamphone & Terpene & $\begin{array}{l}\text { cedar, camphoreous, } \\
\text { woody }\end{array}$ & 1157 & 1157 & {$[180,181]$} \\
\hline 55 & 17.627 & - & - & 0.18 & borneol & Terpene & camphoraceous, earthy & 1163 & 1165 & {$[60,169]$} \\
\hline 56 & 17.674 & - & - & 0.27 & (Z, Z)-3,6-nonadien-1-ol & Alcohol & green, marine, seaweed & 1165 & 1165 & {$[50,182]$} \\
\hline 57 & 17.847 & - & - & 0.04 & cis-pinocamphone & Terpene & $\begin{array}{l}\text { cedar, camphoreous, } \\
\text { woody }\end{array}$ & 1171 & 1172 & [181] \\
\hline 58 & 17.925 & 0.21 & - & - & ethyl benzoate & Ester & flowery & 1173 & 1172 & {$[156,183]$} \\
\hline
\end{tabular}


Table A1. Cont.

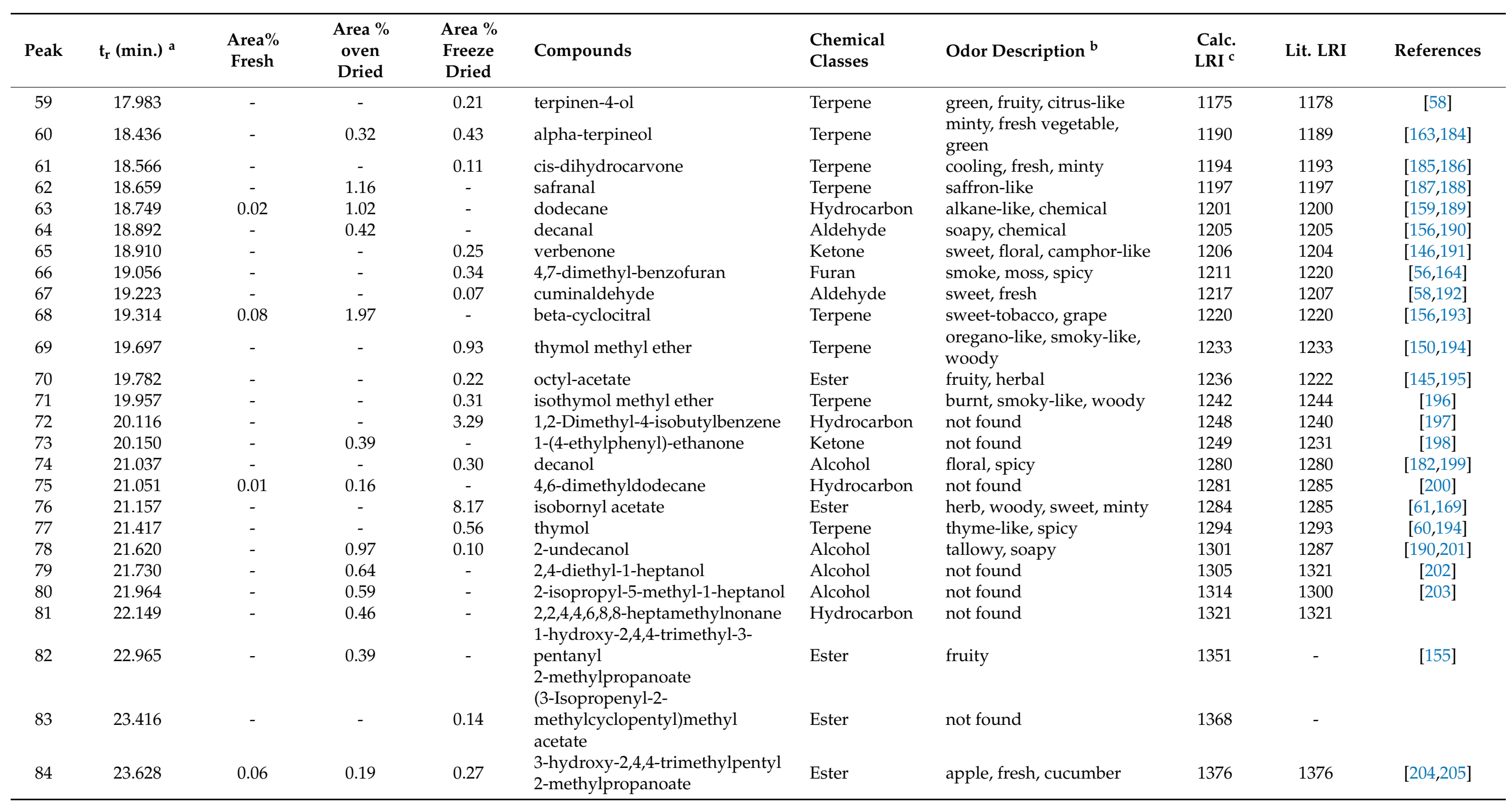


Table A1. Cont.

\begin{tabular}{|c|c|c|c|c|c|c|c|c|c|c|}
\hline Peak & $t_{r}(\min .)^{a}$ & $\begin{array}{l}\text { Area\% } \\
\text { Fresh }\end{array}$ & $\begin{array}{c}\text { Area \% } \\
\text { oven } \\
\text { Dried }\end{array}$ & $\begin{array}{c}\text { Area \% } \\
\text { Freeze } \\
\text { Dried }\end{array}$ & Compounds & $\begin{array}{l}\text { Chemical } \\
\text { Classes }\end{array}$ & Odor Description ${ }^{b}$ & $\begin{array}{l}\text { Calc. } \\
\text { LRI }^{c}\end{array}$ & Lit. LRI & References \\
\hline 85 & 24.238 & - & 0.75 & - & tetradecane & Hydrocarbon & alkane-like, chemical & 1399 & 1413 & {$[189,206]$} \\
\hline 87 & 24.730 & - & - & 0.11 & trans-caryophyllene & Terpene & fresh, fruity, citrus & 1418 & 1419 & {$[58,59,184]$} \\
\hline 88 & 24.813 & - & - & 0.37 & $\begin{array}{l}\text { thymohydroquinone dimethyl } \\
\text { ether }\end{array}$ & Terpene & earthy, moldy & 1422 & 1426 & {$[208,209]$} \\
\hline 89 & 25.048 & - & - & 0.24 & $\gamma$-Elemene & Terpene & green, citrus, floral & 1431 & 1434 & {$[58,210]$} \\
\hline 91 & 25.349 & - & - & 2.10 & geranyl acetone & Ketone & fresh, green & 1443 & 1449 & {$[149,168]$} \\
\hline 92 & 25.603 & - & 0.24 & 0.15 & (E)-nerylacetone & Ketone & rose, fresh, green, magnolia & 1454 & 1452 & {$[213,214]$} \\
\hline 93 & 25.810 & - & 0.24 & - & $\gamma$-decalactone & Lactone & candy, sweet & 1462 & 1467 & $\begin{array}{c}{[55,141,149,} \\
168]\end{array}$ \\
\hline 94 & 26.350 & - & 0.52 & - & $\begin{array}{l}\text { 4-(2,6,6-trimethylcyclohexa-1,3- } \\
\text { dienyl)but-3-en-2-one }\end{array}$ & Ketone & not found & 1483 & 1483 & [215] \\
\hline 95 & 26.412 & - & 1.49 & - & beta-ionone & Ketone & dry fruit, floral & 1486 & 1486 & {$[55,168]$} \\
\hline 96 & 26.644 & - & 0.22 & - & pentadecane & Hydrocarbon & herbaceous & 1495 & 1500 & {$[58,168]$} \\
\hline 97 & 26.692 & 0.06 & - & - & valencene & Terpene & fruity, flowery & 1496 & 1496 & {$[58,216,217]$} \\
\hline 99 & 27.470 & - & 1.26 & - & dihydroactinidiolide & Lactone & coumarin-like, musky & 1529 & 1528 & {$[220,221]$} \\
\hline 100 & 30.835 & - & - & 0.11 & 1-heptadecene & Hydrocarbon & earthy, moss & 1677 & 1673 & {$[157,222]$} \\
\hline
\end{tabular}

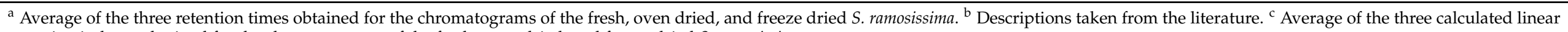
retention indexes obtained for the chromatograms of the fresh, oven dried, and freeze dried S. ramosissima. 


\section{References}

1. Flowers, T.J.; Colmer, T.D. Salinity tolerance in halophytes. New Phytol. 2008, 179, 945-963. [CrossRef]

2. Panta, S.; Flowers, T.; Lane, P.; Doyle, R.; Haros, G.; Shabala, S. Halophyte agriculture: Success stories. Environ. Exp. Bot. 2014, 107, 71-83. [CrossRef]

3. Duarte, B.; Santos, D.; Marques, J.C.; Caçador, I. Ecophysiological adaptations of two halophytes to salt stress: Photosynthesis, PS II photochemistry and anti-oxidant feedback-Implications for resilience in climate change. Plant Physiol. Biochem. 2013, 67, 178-188. [CrossRef] [PubMed]

4. Duarte, B.; Caçador, I.; Matos, A.R. Lipid landscape remodelling in Sarcocornia fruticosa green and red physiotypes. Plant Physiol. Biochem. 2020, 157, 128-137. [CrossRef] [PubMed]

5. Pedro, C.A.; Santos, M.S.S.; Ferreira, S.M.F.; Gonçalves, S.C. The influence of cadmium contamination and salinity on the survival, growth and phytoremediation capacity of the saltmarsh plant Salicornia ramosissima. Mar. Environ. Res. 2013, 92, 197-205. [CrossRef]

6. Duarte, B.; Caçador, I. Iberian Halophytes as Agroecological Solutions for Degraded Lands and Biosaline Agriculture. Sustainability 2021, 13, 1005. [CrossRef]

7. Barreira, L.; Resek, E.; Rodrigues, M.J.; Rocha, M.I.; Pereira, H.; Bandarra, N.; da Silva, M.M.; Varela, J.; Custódio, L. Halophytes: Gourmet food with nutritional health benefits? J. Food Compos. Anal. 2017, 59, 35-42. [CrossRef]

8. Lopes, M.; Cavaleiro, C.; Ramos, F. Sodium Reduction in Bread: A Role for Glasswort (Salicornia ramosissima J. Woods). Compr. Rev. Food Sci. Food Saf. 2017, 16, 1056-1071. [CrossRef] [PubMed]

9. Ventura, Y.; Sagi, M. Halophyte crop cultivation: The case for salicornia and sarcocornia. Environ. Exp. Bot. 2013, 92, 144-153. [CrossRef]

10. Lima, A.R.; Castañeda-Loaiza, V.; Salazar, M.; Nunes, C.; Quintas, C.; Gama, F.; Pestana, M.; Correia, P.J.; Santos, T.; Varela, J.; et al. Influence of cultivation salinity in the nutritional composition, antioxidant capacity and microbial quality of Salicornia ramosissima commercially produced in soilless systems. Food Chem. 2020, 333, 127525. [CrossRef]

11. Rocha, L.D.; Monteiro, M.C.; Teodoro, A.J. Anticancer Properties of Hydroxycinnamic Acids-A Review. Cancer Clin. Oncol. 2012, 1, 109-121. [CrossRef]

12. Onakpoya, I.J.; Spencer, E.A.; Thompson, M.J.; Heneghan, C.J. The effect of chlorogenic acid on blood pressure: A systematic review and meta-analysis of randomized clinical trials. J. Hum. Hypertens. 2015, 29, 77-81. [CrossRef]

13. Maaliki, D.; Shaito, A.A.; Pintus, G.; El-Yazbi, A.; Eid, A.H. Flavonoids in hypertension: A brief review of the underlying mechanisms. Curr. Opin. Pharmacol. 2019, 45, 57-65. [CrossRef] [PubMed]

14. Pan, Y.; Zheng, Y.M.; Ho, W.S. Effect of quercetin glucosides from allium extracts on hepG2, PC-3 AND HT-29 cancer cell lines. Oncol. Lett. 2018, 15, 4657-4661. [CrossRef]

15. Surget, G.; Stiger-Pouvreau, V.; Le Lann, K.; Kervarec, N.; Couteau, C.; Coiffard, L.J.M.; Gaillard, F.; Cahier, K.; Guérard, F.; Poupart, N. Structural elucidation, in vitro antioxidant and photoprotective capacities of a purified polyphenolic-enriched fraction from a saltmarsh plant. J. Photochem. Photobiol. B Biol. 2015, 143, 52-60. [CrossRef] [PubMed]

16. Ferreira, D.; Isca, V.M.S.; Leal, P.; Seca, A.M.L.; Silva, H.; de Lourdes Pereira, M.; Silva, A.M.S.; Pinto, D.C.G.A. Salicornia ramosissima: Secondary metabolites and protective effect against acute testicular toxicity. Arab. J. Chem. 2018, 11, 70-80. [CrossRef]

17. Petropoulos, S.A.; Karkanis, A.; Martins, N.; Ferreira, I.C.F.R. Edible halophytes of the Mediterranean basin: Potential candidates for novel food products. Trends Food Sci. Technol. 2018, 74, 69-84. [CrossRef]

18. Toqeer, S.; Qasim, M.; Abideen, Z.; Gul, B.; Rasheed, M.; Khan, M.A. Chemical Composition and Antioxidant Activity of Seeds of Various Halophytic Grasses. JAOCS J. Am. Oil Chem. Soc. 2018, 95, 1285-1295. [CrossRef]

19. Cho, H.D.; Lee, J.H.; Jeong, J.H.; Kim, J.Y.; Yee, S.T.; Park, S.K.; Lee, M.K.; Seo, K. Il Production of novel vinegar having antioxidant and anti-fatigue activities from Salicornia herbacea L. J. Sci. Food Agric. 2016, 96, 1085-1092. [CrossRef]

20. Wang, L.; Zhang, M.; Mujumdar, A.S.; Wang, Y.; Zhu, C. Restructured crispy fish cubes containing Salicornia bigelovii Torr. developed with microwave vacuum drying. J. Aquat. Food Prod. Technol. 2013, 22, 226-240. [CrossRef]

21. Barroca, M.J.; Guiné, R.P.F.; Amado, A.M.; Ressurreição, S.; da Silva, A.M.; Marques, M.P.M.; de Carvalho, L.A.E.B. The drying process of Sarcocornia perennis: Impact on nutritional and physico-chemical properties. J. Food Sci. Technol. 2020, 57, 4443-4458. [CrossRef] [PubMed]

22. Castroviejo, S.; Botánico, R.J. Flora Ibérica, Plantas Vasculares de la Península Ibérica, e Islas Baleares, Volume II; Real Jardín Botánico, C.S.I.C.: Madrid, Spain, 1990.

23. AOAC Association of Official Analytical Chemists. Official Methods of Analysis of AOAC International, 19th ed.; AOAC International: Washington, DC, USA, 2012.

24. Cruz de Carvalho, R.; Feijão, E.; Kletschkus, E.; Marques, J.C.; Reis-Santos, P.; Fonseca, V.F.; Papenbrock, J.; Caçador, I.; Duarte, B. Halophyte bio-optical phenotyping: A multivariate photochemical pressure index (Multi-PPI) to classify salt marsh anthropogenic pressures levels. Ecol. Indic. 2020, 119, 106816. [CrossRef]

25. Sghaier, D.B.; Pedro, S.; Diniz, M.S.; Duarte, B.; Caçador, I.; Sleimi, N. Tissue localization and distribution of as and al in the halophyte Tamarix gallica under controlled conditions. Front. Mar. Sci. 2016, 3, 274. [CrossRef] 
26. Towett, E.K.; Shepherd, K.D.; Cadisch, G. Quantification of total element concentrations in soils using total X-ray fluorescence spectroscopy (TXRF). Sci. Total Environ. 2013, 463-464, 374-388. [CrossRef] [PubMed]

27. Castello, G. Retention index systems: Alternatives to the n-alkanes as calibration standards. J. Chromatogr. A 1999, 842, 51-64. [CrossRef]

28. Van Den Dool, H.; Kratz, P.D. A Generalization of the Retention Index System including Linear Temperature Programmed Gas-Liquid Partition Chromatography. J. Chromatogr. 1963, 11, 463-471. [CrossRef]

29. Swain, T.; Hillis, W.E. The phenolic constituents of Prunus domestica. I.-The quantitative analysis of phenolic constituents. J. Sci. Food Agric. 1959, 10, 63-68. [CrossRef]

30. Singleton, V.L.; Rossi, J.A. Colorimetry of Total Phenolics with Phosphomolybdic-Phosphotungstic Acid Reagents. Am. J. Enol. Vitic. 1965, 16, 144-158.

31. Huang, D.; Ou, B.; Hampsch-Woodill, M.; Flanagan, J.A.; Prior, R.L. High-throughput assay of oxygen radical absorbance capacity (ORAC) using a multichannel liquid handling system coupled with a microplate fluorescence reader in 96-well format. J. Agric. Food Chem. 2002, 50, 4437-4444. [CrossRef]

32. Serra, A.T.; Duarte, R.O.; Bronze, M.R.; Duarte, C.M.M. Identification of bioactive response in traditional cherries from Portugal. Food Chem. 2011, 125, 318-325. [CrossRef]

33. Moore, J.; Yin, J.J.; Yu, L. Novel fluorometric assay for hydroxyl radical scavenging capacity (HOSC) estimation. J. Agric. Food Chem. 2006, 54, 617-626. [CrossRef]

34. Pereira, L.P.; Silva, P.; Duarte, M.; Rodrigues, L.; Duarte, C.M.M.; Albuquerque, C.; Serra, A.T. Targeting colorectal cancer proliferation, stemness and metastatic potential using Brassicaceae extracts enriched in isothiocyanates: A 3D cell model-based study. Nutrients 2017, 9, 368. [CrossRef]

35. Oliveira-Alves, S.C.; Pereira, R.S.; Pereira, A.B.; Ferreira, A.; Mecha, E.; Silva, A.B.; Serra, A.T.; Bronze, M.R. Identification of functional compounds in baru (Dipteryx alata Vog.) nuts: Nutritional value, volatile and phenolic composition, antioxidant activity and antiproliferative effect. Food Res. Int. 2020, 131, 109026. [CrossRef]

36. Castañeda-Loaiza, V.; Placines, C.; Rodrigues, M.J.; Pereira, C.; Zengin, G.; Uysal, A.; Jeko, J.; Cziáky, Z.; Reis, C.P.; Gaspar, M.M.; et al. If you cannot beat them, join them: Exploring the fruits of the invasive species Carpobrotus edulis (L.) N.E. Br as a source of bioactive products. Ind. Crops Prod. 2020, 144, 112005. [CrossRef]

37. Garcia-Amezquita, L.E.; Tejada-Ortigoza, V.; Campanella, O.H.; Welti-Chanes, J. Influence of Drying Method on the Composition, Physicochemical Properties, and Prebiotic Potential of Dietary Fibre Concentrates from Fruit Peels. J. Food Qual. 2018, 2018, 9105237. [CrossRef]

38. Nireesha, G.R.; Divya, L.; Sowmya, C.; Venkateshan, N.; Niranjan Babu, M.; Lavakumar, V. Lyophilization/Freeze Drying-An Review. Int. J. Novel Trends Pharm. Sci. 2013, 3, 87-98.

39. Zhang, J.; Zhou, D.; Zhong, X.; Pei, Z.; Tian, Y.; Xiang, D.; Cao, J.; Shen, X.; Li, C. Quality and protein degradation of golden pompano (Trachinotus blochii) fillets during four drying methods. LWT 2020, 130, 109638. [CrossRef]

40. Alakali, J.S.; Kucha, C.T.; Rabiu, I.A. Effect of drying temperature on the nutritional quality of Moringa oleifera leaves. Afr. J. Food Sci. 2015, 9, 395-399. [CrossRef]

41. Siriwattananon, L.; Maneerate, J. Effect of drying methods on dietary fiber content in dried fruit and vegetable from non-toxic agricultural field. Int. J. GEOMATE 2016, 11, 2896-2900. [CrossRef]

42. Tejada-Ortigoza, V.; García-Amezquita, L.E.; Serna-Saldívar, S.O.; Welti-Chanes, J. The dietary fiber profile of fruit peels and functionality modifications induced by high hydrostatic pressure treatments. Food Sci. Technol. Int. 2017, 23, 396-402. [CrossRef]

43. Ventura, Y.; Wuddineh, W.A.; Myrzabayeva, M.; Alikulov, Z.; Khozin-Goldberg, I.; Shpigel, M.; Samocha, T.M.; Sagi, M. Effect of seawater concentration on the productivity and nutritional value of annual Salicornia and perennial Sarcocornia halophytes as leafy vegetable crops. Sci. Hortic. 2011, 128, 189-196. [CrossRef]

44. Guil, J.L.; Torija, M.E.; Giménez, J.J.; Rodríguez, I. Identification of fatty acids in edible wild plants by gas chromatography. J. Chromatogr. A 1996, 719, 229-235. [CrossRef]

45. Zárate, R.; Jaber-Vazdekis, N.; Tejera, N.; Pérez, J.A.; Rodríguez, C. Significance of long chain polyunsaturated fatty acids in human health. Clin. Transl. Med. 2017, 6, 25. [CrossRef]

46. Isca, V.M.S.; Seca, A.M.L.; Pinto, D.C.G.A.; Silva, H.; Silva, A.M.S. Lipophilic profile of the edible halophyte Salicornia ramosissima. Food Chem. 2014, 165, 330-336. [CrossRef] [PubMed]

47. Martínez-Yusta, A.; Goicoechea, E.; Guillén, M.D. A Review of Thermo-Oxidative Degradation of Food Lipids Studied by ${ }^{1} \mathrm{H}$ NMR Spectroscopy: Influence of Degradative Conditions and Food Lipid Nature. Compr. Rev. Food Sci. Food Saf. 2014, 13, 838-859. [CrossRef]

48. Rodríguez-Ramos, F.; Leiva-Portilla, D.; Rodríguez-Núñez, K.; Pacheco, P.; Briones-Labarca, V. Mathematical modeling and quality parameters of Salicornia fruticosa dried by convective drying. J. Food Sci. Technol. 2021, 58, 474-483. [CrossRef]

49. Sharma, A.; Gontia, I.; Agarwal, P.K.; Jha, B. Accumulation of heavy metals and its biochemical responses in Salicornia brachiata, an extreme halophyte. Mar. Biol. Res. 2010, 6, 511-518. [CrossRef]

50. Delort, E.; Jaquier, A.; Chapuis, C.; Rubin, M.; Starkenmann, C. Volatile composition of oyster leaf (Mertensia maritima (L.) Gray). J. Agric. Food Chem. 2012, 60, 11681-11690. [CrossRef]

51. Sugisawa, H.; Nakamura, K.; Tamura, H. The aroma profile of the volatiles in marine green algae (ulva pertusa). Food Rev. Int. 1990, 6, 573-589. [CrossRef] 
52. Aparicio, R.; Morales, M.T. Characterization of Olive Ripeness by Green Aroma Compounds of Virgin Olive Oil. J. Agric. Food Chem. 1998, 46, 1116-1122. [CrossRef]

53. Lykomitros, D.; Fogliano, V.; Capuano, E. Flavor of roasted peanuts (Arachis hypogaea)—Part II: Correlation of volatile compounds to sensory characteristics. Food Res. Int. 2016, 89, 870-881. [CrossRef]

54. Sánchez-García, F.; Mirzayeva, A.; Roldán, A.; Castro, R.; Palacios, V.; García-Barroso, C.; Durán-Guerrero, E. Evolution of volatile compounds and sensory characteristics of edible green seaweed (Ulva rigida) during storage at different temperatures. J. Sci. Food Agric. 2019, 99, 5475-5482. [CrossRef]

55. Wang, Y.; Finn, C.; Qian, M.C. Impact of growing environment on Chickasaw blackberry (Rubus L.) aroma evaluated by gas chromatography olfactometry dilution analysis. J. Agric. Food Chem. 2005, 53, 3563-3571. [CrossRef] [PubMed]

56. Varlet, V.; Knockaert, C.; Prost, C.; Serot, T. Comparison of odor-active volatile compounds of fresh and smoked salmon. J. Agric. Food Chem. 2006, 54, 3391-3401. [CrossRef] [PubMed]

57. Aisala, H.; Sola, J.; Hopia, A.; Linderborg, K.M.; Sandell, M. Odor-contributing volatile compounds of wild edible Nordic mushrooms analyzed with HS-SPME-GC-MS and HS-SPME-GC-O/FID. Food Chem. 2019, 283, 566-578. [CrossRef]

58. Choi, H.S. Characteristic odor components of kumquat (Fortunella japonica Swingle) peel oil. J. Agric. Food Chem. 2005, 53, 1642-1647. [CrossRef]

59. Tu, N.T.M.; Onishi, Y.; Choi, H.S.; Kondo, Y.; Bassore, S.M.; Ukeda, H.; Sawamura, M. Characteristic odor components of Citrus sphaerocarpa Tanaka (Kabosu) cold-pressed peel oil. J. Agric. Food Chem. 2002, 50, 2908-2913. [CrossRef]

60. Jirovetz, L.; Buchbauer, G.; Denkova, Z.; Slavchev, A.; Stoyanova, A.; Schmidt, E. Chemical composition, antimicrobial activities and odor descriptions of various Salvia sp. and Thuja sp. essential oils. Nutrition-Vienna 2006, 30, 152.

61. Niu, Y.; Wang, P.; Xiao, Q.; Xiao, Z.; Mao, H.; Zhang, J. Characterization of odor-active volatiles and odor contribution based on binary interaction effects in mango and vodka cocktail. Molecules 2020, 25, 1083. [CrossRef]

62. Keskin, M.; Özkök, A. Effects of drying techniques on chemical composition and volatile constituents of bee pollen. Czech J. Food Sci. 2020, 38, 203-208. [CrossRef]

63. Alasalvar, C.; Shahidi, F.; Cadwallader, K.R. Comparison of natural and roasted Turkish Tombul hazelnut (Corylus avellana L.) volatiles and flavor by DHA/GC/MS and descriptive sensory analysis. J. Agric. Food Chem. 2003, 51, 5067-5072. [CrossRef]

64. Poisson, L.; Blank, I.; Dunkel, A.; Hofmann, T. The Chemistry of Roasting-Decoding Flavor Formation. In The Craft and Science of Coffee; Academic Press: Cambridge, MA, USA, 2017; pp. 273-309. [CrossRef]

65. de Torres, C.; Díaz-Maroto, M.C.; Hermosín-Gutiérrez, I.; Pérez-Coello, M.S. Effect of freeze-drying and oven-drying on volatiles and phenolics composition of grape skin. Anal. Chim. Acta 2010, 660, 177-182. [CrossRef] [PubMed]

66. Özkan-Karabacak, A.; Özcan-Sinir, G.; Utku Çopur, Ö. Effects of Drying Methods on the Composition of Volatile Compounds in Fruits and Vegetables; Verlag der Technischen Universität Graz: Graz, Austria, 2018. [CrossRef]

67. Renna, M.; Gonnella, M. The use of the sea fennel as a new spice-colorant in culinary preparations. Int. J. Gastron. Food Sci. 2012, 1,111-115. [CrossRef]

68. Giungato, P.; Renna, M.; Rana, R.; Licen, S.; Barbieri, P. Characterization of dried and freeze-dried sea fennel (Crithmum maritimum L.) samples with headspace gas-chromatography/mass spectrometry and evaluation of an electronic nose discrimination potential. Food Res. Int. 2019, 115, 65-72. [CrossRef]

69. Oliveira-Alves, S.C.; Vendramini-Costa, D.B.; Betim Cazarin, C.B.; Maróstica Júnior, M.R.; Borges Ferreira, J.P.; Silva, A.B.; Prado, M.A.; Bronze, M.R. Characterization of phenolic compounds in chia (Salvia hispanica L.) seeds, fiber flour and oil. Food Chem. 2017, 232, 295-305. [CrossRef]

70. Spínola, V.; Pinto, J.; Castilho, P.C. Identification and quantification of phenolic compounds of selected fruits from Madeira Island by HPLC-DAD-ESI-MSn and screening for their antioxidant activity. Food Chem. 2015, 173, 14-30. [CrossRef] [PubMed]

71. Sánchez-Salcedo, E.M.; Tassotti, M.; Del Rio, D.; Hernández, F.; Martínez, J.J.; Mena, P. (Poly)phenolic fingerprint and chemometric analysis of white (Morus alba L.) and black (Morus nigra L.) mulberry leaves by using a non-targeted UHPLC-MS approach. Food Chem. 2016, 212, 250-255. [CrossRef]

72. Kelebek, H.; Sevindik, O.; Selli, S. LC-DAD-ESI-MS/MS-based phenolic profiling of St John's Wort Teas and their antioxidant activity: Eliciting infusion induced changes. J. Liq. Chromatogr. Relat. Technol. 2019, 42, 9-15. [CrossRef]

73. Zwyrzykowska, A.; Kupczyński, R.; Jarosz, B.; Szumny, A.; Kucharska, A.Z. Qualitative and quantitative analysis of polyphenolic compounds in Ilex Sp. Open Chem. 2015, 13, 1303-1312. [CrossRef]

74. Gonthier, M.P.; Verny, M.A.; Besson, C.; Rémésy, C.; Scalbert, A. Chlorogenic acid bioavailability largely depends on its metabolism by the gut microflora in rats. J. Nutr. 2003, 133, 1853-1859. [CrossRef]

75. David, M.; Antos, S.; Lmeida, C.A.; Opes, N.P.L.; Emília, G.; Ouza, P.D.S. Evaluation of the Anti-inflammatory, Analgesic and Antipyretic Activities of the Natural Polyphenol Chlorogenic Acid. Biol. Pharm. Bull. 2006, 29, 2236-2240.

76. Naveed, M.; Hejazi, V.; Abbas, M.; Kamboh, A.A.; Khan, G.J.; Shumzaid, M.; Ahmad, F.; Babazadeh, D.; FangFang, X.; ModarresiGhazani, F.; et al. Chlorogenic acid (CGA): A pharmacological review and call for further research. Biomed. Pharmacother. 2018, 97, 67-74. [CrossRef] [PubMed]

77. Lu, H.; Tian, Z.; Cui, Y.; Liu, Z.; Ma, X. Chlorogenic acid: A comprehensive review of the dietary sources, processing effects, bioavailability, beneficial properties, mechanisms of action, and future directions. Compr. Rev. Food Sci. Food Saf. 2020, 19, 3130-3158. [CrossRef] 
78. Alves-Silva, J.M.; Guerra, I.; Gonçalves, M.J.; Cavaleiro, C.; Cruz, M.T.; Figueirinha, A.; Salgueiro, L. Chemical composition of Crithmum maritimum L. essential oil and hydrodistillation residual water by GC-MS and HPLC-DAD-MS/MS, and their biological activities. Ind. Crops Prod. 2020, 149, 112329. [CrossRef]

79. Mishima, S.; Yoshida, C.; Akino, S.; Sakamoto, T. Antihypertensive effects of Brazilian propolis: Identification of caffeoylquinic acids as constituents involved in the hypotension in spontaneously hypertensive rats. Biol. Pharm. Bull. 2005, 28, 1909-1914. [CrossRef] [PubMed]

80. Simeonova, R.; Vitcheva, V.; Zheleva-Dimitrova, D.; Balabanova, V.; Savov, I.; Yagi, S.; Dimitrova, B.; Voynikov, Y.; Gevrenova, R. Trans-3,5-dicaffeoylquinic acid from Geigeria alata Benth. \& Hook.f. ex Oliv. \& Hiern with beneficial effects on experimental diabetes in animal model of essential hypertension. Food Chem. Toxicol. 2019, 132, 110678. [CrossRef]

81. Yin, X.L.; Xu, B.Q.; Zhang, Y.Q. Gynura divaricata rich in 3, 5-/4, 5-dicaffeoylquinic acid and chlorogenic acid reduces islet cell apoptosis and improves pancreatic function in type 2 diabetic mice. Nutr. Metab. 2018, 15, 73. [CrossRef]

82. Ayouaz, S.; Oliveira-Alves, S.C.; Lefsih, K.; Serra, A.T.; Bento Da Silva, A.; Samah, M.; Karczewski, J.; Madani, K.; Bronze, M.R. Phenolic compounds from Nerium oleander leaves: Microwave assisted extraction, characterization, antiproliferative and cytotoxic activities. Food Funct. 2020, 11, 6319-6331. [CrossRef]

83. Lin, L.Z.; Harnly, J.M. A screening method for the identification of glycosylated flavonoids and other phenolic compounds using a standard analytical approach for all plant materials. J. Agric. Food Chem. 2007, 55, 1084-1096. [CrossRef]

84. Njenga, P.K.; Mugo, S.M.; Zhou, T. Characterization of Polyphenols, Flavonoids and Their Anti-microbial Activity in the Fruits of Vangueria madagascariensis J. F. Gmel. Eur. J. Med. Plants 2020, 31, 24-37. [CrossRef]

85. Iacopini, P.; Baldi, M.; Storchi, P.; Sebastiani, L. Catechin, epicatechin, quercetin, rutin and resveratrol in red grape: Content, in vitro antioxidant activity and interactions. J. Food Compos. Anal. 2008, 21, 589-598. [CrossRef]

86. Wang, W.; Sun, C.; Mao, L.; Ma, P.; Liu, F.; Yang, J.; Gao, Y. The biological activities, chemical stability, metabolism and delivery systems of quercetin: A review. Trends Food Sci. Technol. 2016, 56, 21-38. [CrossRef]

87. Mata, A.; Ferreira, J.P.; Semedo, C.; Serra, T.; Duarte, C.M.M.; Bronze, M.R. Contribution to the characterization of Opuntia spp. juices by LC-DAD-ESI-MS/MS. Food Chem. 2016, 210, 558-565. [CrossRef]

88. Vallverdú-Queralt, A.; Jáuregui, O.; Medina-Remón, A.; Andrés-Lacueva, C.; Lamuela-Raventós, R.M. Improved characterization of tomato polyphenols using liquid chromatography/electrospray ionization linear ion trap quadrupole Orbitrap mass spectrometry and liquid chromatography/electrospray ionization tandem mass spectrometry. Rapid Commun. Mass Spectrom. 2010, 24, 2986-2992. [CrossRef] [PubMed]

89. Hossain, M.B.; Rai, D.K.; Brunton, N.P.; Martin-Diana, A.B.; Barry-Ryan, A.C. Characterization of phenolic composition in lamiaceae spices by LC-ESI-MS/MS. J. Agric. Food Chem. 2010, 58, 10576-10581. [CrossRef]

90. Nabet, N.; Gilbert-López, B.; Madani, K.; Herrero, M.; Ibáñez, E.; Mendiola, J.A. Optimization of microwave-assisted extraction recovery of bioactive compounds from Origanum glandulosum and Thymus fontanesii. Ind. Crops Prod. 2019, 129, 395-404. [CrossRef]

91. Wilbert, S.M.; Ericsson, L.H.; Gordon, M.P. Quantification of jasmonic acid, methyl jasmonate, and salicylic acid in plants by capillary liquid chromatography electrospray tandem mass spectrometry. Anal. Biochem. 1998, 257, 186-194. [CrossRef]

92. Fang, N.; Yu, S.; Prior, R.L. LC/MS/MS characterization of phenolic constituents in dried plums. J. Agric. Food Chem. 2002, 50, 3579-3585. [CrossRef]

93. Ye, M.; Yang, W.Z.; Liu, K.D.; Qiao, X.; Li, B.J.; Cheng, J.; Feng, J.; Guo, D.A.; Zhao, Y.Y. Characterization of flavonoids in Millettia nitida var. hirsutissima by HPLC/DAD/ESI-MSn. J. Pharm. Anal. 2012, 2, 35-42. [CrossRef] [PubMed]

94. Chandrasekara, A.; Shahidi, F. Determination of antioxidant activity in free and hydrolyzed fractions of millet grains and characterization of their phenolic profiles by HPLC-DAD-ESI-MSn. J. Funct. Foods 2011, 3, 144-158. [CrossRef]

95. Barros, L.; Dueñas, M.; Carvalho, A.M.; Ferreira, I.C.F.R.; Santos-Buelga, C. Characterization of phenolic compounds in flowers of wild medicinal plants from Northeastern Portugal. Food Chem. Toxicol. 2012, 50, 1576-1582. [CrossRef]

96. Nabet, N.; Boudries, H.; Chougui, N.; Loupassaki, S.; Souagui, S.; Burló, F.; Hernández, F.; Carbonell-Barrachina, Á.A.; Madani, K.; Larbat, R. Biological activities and secondary compound composition from Crithmum maritimum aerial parts. Int. J. Food Prop. 2017, 20, 1843-1855. [CrossRef]

97. Kang, J.; Price, W.E.; Ashton, J.; Tapsell, L.C.; Johnson, S. Identification and characterization of phenolic compounds in hydromethanolic extracts of sorghum wholegrains by LC-ESI-MSn. Food Chem. 2016, 211, 215-226. [CrossRef] [PubMed]

98. Engels, C.; Gräter, D.; Esquivel, P.; Jiménez, V.M.; Gänzle, M.G.; Schieber, A. Characterization of phenolic compounds in jocote (Spondias purpurea L.) peels by ultra high-performance liquid chromatography/electrospray ionization mass spectrometry. Food Res. Int. 2012, 46, 557-562. [CrossRef]

99. Pellati, F.; Orlandini, G.; Pinetti, D.; Benvenuti, S. HPLC-DAD and HPLC-ESI-MS/MS methods for metabolite profiling of propolis extracts. J. Pharm. Biomed. Anal. 2011, 55, 934-948. [CrossRef] [PubMed]

100. Xu, X.; Pu, R.; Li, Y.; Wu, Z.; Li, C.; Miao, X.; Yang, W. Chemical Compositions of Propolis from China and the United States and their Antimicrobial Activities Against Penicillium notatum. Molecules 2019, 24, 3576. [CrossRef] [PubMed]

101. Falcão, S.I.; Vilas-Boas, M.; Estevinho, L.M.; Barros, C.; Domingues, M.R.M.; Cardoso, S.M. Phenolic characterization of Northeast Portuguese propolis: Usual and unusual compounds. Anal. Bioanal. Chem. 2010, 396, 887-897. [CrossRef] 
102. Ziani, B.E.C.; Barros, L.; Boumehira, A.Z.; Bachari, K.; Heleno, S.A.; Alves, M.J.; Ferreira, I.C.F.R. Profiling polyphenol composition by HPLC-DAD-ESI/MSn and the antibacterial activity of infusion preparations obtained from four medicinal plants. Food Funct. 2018, 9, 149-159. [CrossRef]

103. Simirgiotis, M.; Schmeda-Hirschmann, G.; Bórquez, J.; Kennelly, E. The Passiflora tripartita (Banana passion) Fruit: A Source of Bioactive Flavonoid C-Glycosides Isolated by HSCCC and Characterized by HPLC-DAD-ESI/MS/MS. Molecules 2013, 18, 1672-1692. [CrossRef]

104. Llorach, R.; Gil-Izquierdo, A.; Ferreres, F.; Tomás-Barberán, F.A. HPLC-DAD-MS/MS ESI characterization of unusual highly glycosylated acylated flavonoids from cauliflower (Brassica oleracea L. var. botrytis) agroindustrial byproducts. J. Agric. Food Chem. 2003, 51, 3895-3899. [CrossRef]

105. Guerreiro, A.; Rassal, C.; Afonso, C.M.; Galego, L.; Serra, M.; Rodrigues, M.A. Healthy, Tasty and Sustainable Mediterranean Food. UMAMI Taste and Polyphenols of Twiggy Glasswort (Salicornia ramosissima). In INCREaSE; Springer International Publishing: Berlin/Heidelberg, Germany, 2018; pp. 191-198.

106. Kim, J.Y.; Cho, J.Y.; Ma, Y.K.; Park, K.Y.; Lee, S.H.; Ham, K.S.; Lee, H.J.; Park, K.H.; Moon, J.H. Dicaffeoylquinic acid derivatives and flavonoid glucosides from glasswort (Salicornia herbacea L.) and their antioxidative activity. Food Chem. 2011, 125, 55-62. [CrossRef]

107. Kim, K.S. Isolation and Identification of Antioxidant Flavonoids from Salicornia herbacea L. Appl. Biol. Chem. 2004, 47, 120-123.

108. Joardder, M.U.H.; Karim, A.; Kumar, C.; Brown, R.J. Porosity—Stablishing the Relationship between Drying Parameters and Dried Food Quality; SpringerBriefs in Food, Health and Nutrition; Springer International Publishing: Cham, Switzerland, 2016; ISBN 978-3-319-23044-3.

109. Çoklar, H.; Akbulut, M. Effect of Sun, Oven and Freeze-Drying on Anthocyanins, Phenolic Compounds and Antioxidant Activity of Black Grape (Ekşikara) (Vitis vinifera L.). S. Afr. J. Enol. Vitic. 2017, 38, 264-272. [CrossRef]

110. Belščak-Cvitanović, A.; Durgo, K.; Huđek, A.; Bačun-Družina, V.; Komes, D. Overview of polyphenols and their properties. In Polyphenols: Properties, Recovery, and Applications; Woodhead Publishing: Cambridge, UK, 2018; pp. 3-44. [CrossRef]

111. Chua, L.Y.W.; Chong, C.H.; Chua, B.L.; Figiel, A. Influence of Drying Methods on the Antibacterial, Antioxidant and Essential Oil Volatile Composition of Herbs: A Review. Food Bioprocess Technol. 2019, 12, 450-476. [CrossRef]

112. Thamkaew, G.; Sjöholm, I.; Galindo, F.G. A review of drying methods for improving the quality of dried herbs. Crit. Rev. Food Sci. Nutr. 2021, 61, 1763-1786. [CrossRef]

113. Madrau, M.A.; Piscopo, A.; Sanguinetti, A.M.; Del Caro, A.; Poiana, M.; Romeo, F.V.; Piga, A. Effect of drying temperature on polyphenolic content and antioxidant activity of apricots. Eur. Food Res. Technol. 2009, 228, 441-448. [CrossRef]

114. Mogol, B.A.; Yildirim, A.; Gökmen, V. Inhibition of enzymatic browning in actual food systems by the Maillard reaction products. J. Sci. Food Agric. 2010, 90, 2556-2562. [CrossRef]

115. McSweeney, M.; Seetharaman, K. State of Polyphenols in the Drying Process of Fruits and Vegetables. Crit. Rev. Food Sci. Nutr. 2015, 55, 660-669. [CrossRef] [PubMed]

116. Piga, A.; Del Caro, A.; Corda, G. From plums to prunes: Influence of drying parameters on polyphenols and antioxidant activity. J. Agric. Food Chem. 2003, 51, 3675-3681. [CrossRef] [PubMed]

117. Isabelle, M.; Lee, B.L.; Lim, M.T.; Koh, W.P.; Huang, D.; Ong, C.N. Antioxidant activity and profiles of common vegetables in Singapore. Food Chem. 2010, 120, 993-1003. [CrossRef]

118. Rababah, T.M.; Ereifej, K.I.; Esoh, R.B.; Al-u'datt, M.H.; Alrababah, M.A.; Yang, W. Antioxidant activities, total phenolics and HPLC analyses of the phenolic compounds of extracts from common Mediterranean plants. Nat. Prod. Res. 2011, 25, 596-605. [CrossRef]

119. Cristina, C.; Lucia, P.; Sara, S.; Francesco, S.; Nobile Matteo Alessandro, D.; Amalia, C. Study of the Efficacy of Two Extraction Techniques from Crithmum maritimum and Salicornia europaea. J. Food Nutr. Res. 2018, 6, 456-463. [CrossRef]

120. Banjarnahor, S.D.S.; Artanti, N. Antioxidant properties of flavonoids. Med. J. Indones. 2014, 23, 239-244. [CrossRef]

121. Rice-Evans, C.A.; Miller, N.J.; Paganga, G. Structure-antioxidant activity relationships of flavonoids and phenolic acids. Free Radic. Biol. Med. 1996, 20, 933-956. [CrossRef]

122. Kyi, T.M.; Daud, W.R.W.; Mohammad, A.B.; Wahid Samsudin, M.; Kadhum, A.A.H.; Talib, M.Z.M. The kinetics of polyphenol degradation during the drying of Malaysian cocoa beans. Int. J. Food Sci. Technol. 2005, 40, 323-331. [CrossRef]

123. Santos, M.C.; Toson, N.S.B.; Pimentel, M.C.B.; Bordignon, S.A.L.; Mendez, A.S.L.; Henriques, A.T. Polyphenols composition from leaves of Cuphea spp. and inhibitor potential, in vitro, of angiotensin I-converting enzyme (ACE). J. Ethnopharmacol. 2020, 255, 112781. [CrossRef]

124. Ra, J.E.; Woo, S.Y.; Jin, H.; Lee, M.J.; Kim, H.Y.; Ham, H.; Chung, I.M.; Seo, W.D. Evaluation of antihypertensive polyphenols of barley (Hordeum vulgare L.) seedlings via their effects on angiotensin-converting enzyme (ACE) inhibition. Appl. Biol. Chem. 2020, 63, 38. [CrossRef]

125. Nileeka Balasuriya, B.W.; Vasantha Rupasinghe, H.P. Plant flavonoids as angiotensin converting enzyme inhibitors in regulation of hypertension. Funct. Foods Health Dis. 2011, 1, 172-188. [CrossRef]

126. Balasuriya, N.; Rupasinghe, H.P.V. Antihypertensive properties of flavonoid-rich apple peel extract. Food Chem. 2012, 135, 2320-2325. [CrossRef]

127. Murakami, A.; Ashida, H.; Terao, J. Multitargeted cancer prevention by quercetin. Cancer Lett. 2008, 269, 315-325. [CrossRef] 
128. Murad, L.D.; Soares, N.D.C.P.; Brand, C.; Monteiro, M.C.; Teodoro, A.J. Effects of caffeic and 5-caffeoylquinic acids on cell viability and cellular uptake in human colon adenocarcinoma cells. Nutr. Cancer 2015, 67, 532-542. [CrossRef]

129. Glei, M.; Kirmse, A.; Habermann, N.; Persin, C.; Pool-Zobel, B.L. Bread enriched with green coffee extract has chemoprotective and antigenotoxic activities in human cells. Nutr. Cancer 2006, 56, 182-192. [CrossRef]

130. Bhullar, K.S.; Lassalle-Claux, G.; Touaibia, M.; Vasantha Rupasinghe, H.P. Antihypertensive effect of caffeic acid and its analogs through dual renin-angiotensin-aldosterone system inhibition. Eur. J. Pharmacol. 2014, 730, 125-132. [CrossRef] [PubMed]

131. Wang, W.; Li, J.; Zhang, H.; Wang, X.; Fan, J.; Zhang, X. Phenolic compounds and bioactivity evaluation of aqueous and methanol extracts of Allium mongolicum Regel. Food Sci. Nutr. 2019, 7, 779-787. [CrossRef] [PubMed]

132. Kang, S.; Kim, D.; Lee, B.H.; Kim, M.R.; Hong, J.; Chiang, M. Antioxidant properties and cytotoxic effects of fractions from glasswort (Salicornia herbacea) seed extracts on human intestinal cells. Food Sci. Biotechnol. 2011, 20, 115-122. [CrossRef]

133. Jung, B.M.; Park, J.A.; Bae, S.J. Growth inhibitory and quinone reductase induction activities of Salicornia herbacea L. fractions on human cancer cell lines in vitro. J. Korean Soc. Food Sci. Nutr. 2008, 37, 148-153. [CrossRef]

134. Mamadalieva, N.Z.; Herrmann, F.; El-Readi, M.Z.; Tahrani, A.; Hamoud, R.; Egamberdieva, D.R.; Azimova, S.S.; Wink, M. Flavonoids in Scutellaria immaculata and S. ramosissima (Lamiaceae) and their biological activity. J. Pharm. Pharmacol. 2011, 63, 1346-1357. [CrossRef] [PubMed]

135. Sharifi, A.M.; Darabi, R.; Akbarloo, N. Study of antihypertensive mechanism of Tribulus terrestris in 2K1C hypertensive rats: Role of tissue ACE activity. Life Sci. 2003, 73, 2963-2971. [CrossRef] [PubMed]

136. Bankar, G.R.; Nayak, P.G.; Bansal, P.; Paul, P.; Pai, K.S.R.; Singla, R.K.; Bhat, V.G. Vasorelaxant and antihypertensive effect of Cocos nucifera Linn. endocarp on isolated rat thoracic aorta and DOCA salt-induced hypertensive rats. J. Ethnopharmacol. 2011, 134, 50-54. [CrossRef] [PubMed]

137. Cho, J.Y.; Park, K.H.; Hwang, D.Y.; Chanmuang, S.; Jaiswal, L.; Park, Y.K.; Park, S.Y.; Kim, S.Y.; Kim, H.R.; Moon, J.H.; et al. Antihypertensive effects of Artemisia scoparia waldst in spontaneously hypertensive rats and identification of angiotensin I converting enzyme inhibitors. Molecules 2015, 20, 19789-19804. [CrossRef]

138. Ksouri, R.; Ksouri, W.M.; Jallali, I.; Debez, A.; Magné, C.; Hiroko, I.; Abdelly, C. Medicinal halophytes: Potent source of health promoting biomolecules with medical, nutraceutical and food applications. Crit. Rev. Biotechnol. 2012, 32, 289-326. [CrossRef]

139. Phillips, O.A.; Mathew, K.T.; Oriowo, M.A. Antihypertensive and vasodilator effects of methanolic and aqueous extracts of Tribulus terrestris in rats. J. Ethnopharmacol. 2006, 104, 351-355. [CrossRef] [PubMed]

140. Jordán, M.J.; Tandon, K.; Shaw, P.E.; Goodner, K.L. Aromatic profile of aqueous banana essence and banana fruit by gas chromatography-mass spectrometry (GC-MS) and gas chromatography-olfactometry (GC-O). J. Agric. Food Chem. 2001, 49, 4813-4817. [CrossRef] [PubMed]

141. Sampaio, T.S.; Nogueira, P.C.L. Volatile components of mangaba fruit (Hancornia speciosa Gomes) at three stages of maturity. Food Chem. 2006, 95, 606-610. [CrossRef]

142. Tret'yakov, K.V. Retention Data; NIST Mass Spectrometry Data Center. Available online: https://chemdata.nist.gov/ (accessed on 17 July 2021).

143. Baccouri, B.; Temime, S.B.; Campeol, E.; Cioni, P.L.; Daoud, D.; Zarrouk, M. Application of solid-phase microextraction to the analysis of volatile compounds in virgin olive oils from five new cultivars. Food Chem. 2007, 102, 850-856. [CrossRef]

144. Garruti, D.S.; Franco, M.R.B.; Da Silva, M.A.A.P.; Janzantti, N.S.; Alves, G.L. Assessment of aroma impact compounds in a cashew apple-based alcoholic beverage by GC-MS and GC-olfactometry. LWT Food Sci. Technol. 2006, 39, 373-378. [CrossRef]

145. Gürbüz, O.; Rouseff, J.M.; Rouseff, R.L. Comparison of aroma volatiles in commercial merlot and Cabernet Sauvignon wines using gas chromatography-olfactometry and gas chromatography-mass spectrometry. J. Agric. Food Chem. 2006, 54, 3990-3996. [CrossRef] [PubMed]

146. Quijano, C.E.; Linares, D.; Pino, J.A. Changes in volatile compounds of fermented cereza agria [Phyllanthus acidus (L.) Skeels] fruit. Flavour Fragr. J. 2007, 22, 392-394. [CrossRef]

147. García-Aguilar, L.; Rojas-Molina, A.; Ibarra-Alvarado, C.; Rojas-Molina, J.; Vázquez-Landaverde, P.; Luna-Vázquez, F.; ZavalaSánchez, M. Nutritional Value and Volatile Compounds of Black Cherry (Prunus serotina) Seeds. Molecules 2015, 20, $3479-3495$. [CrossRef]

148. Selli, S.; Canbas, A.; Varlet, V.; Kelebek, H.; Prost, C.; Serot, T. Characterization of the most odor-active volatiles of orange wine made from a Turkish cv. Kozan (Citrus sinensis L. Osbeck). J. Agric. Food Chem. 2008, 56, 227-234. [CrossRef]

149. Boulanger, R.; Crouzet, J. Free and bound flavour components of Amazonian fruits: 2. cupuacu volatile compounds. Flavour Fragr. J. 2000, 15, 251-257. [CrossRef]

150. Aligiannis, N.; Kalpoutzakis, E.; Mitaku, S.; Chinou, I.B. Composition and antimicrobial activity of the essential oils of two Origanum species. J. Agric. Food Chem. 2001, 49, 4168-4170. [CrossRef]

151. Stashenko, E.E.; Martínez, J.R.; Ruíz, C.A.; Arias, G.; Durán, C.; Salgar, W.; Cala, M. Lippia origanoides chemotype differentiation based on essential oil GC-MS and principal component analysis. J. Sep. Sci. 2010, 33, 93-103. [CrossRef] [PubMed]

152. Grondin, E.; Shum Cheong Sing, A.; Caro, Y.; de Billerbeck, G.M.; François, J.M.; Petit, T. Physiological and biochemical characteristics of the ethyl tiglate production pathway in the yeast Saprochaete suaveolens. Yeast 2015, 32, 57-66. [CrossRef]

153. Telci, I.; Demirtas, I.; Sahin, A. Variation in plant properties and essential oil composition of sweet fennel (Foeniculum vulgare Mill.) fruits during stages of maturity. Ind. Crops Prod. 2009, 30, 126-130. [CrossRef] 
154. Javidnia, K.; Miri, R.; Kamalinejad, M.; Sarkarzadeh, H.; Jamalian, A. Chemical composition of the essential oils of Anthemis altissima L. grown in Iran. Flavour Fragr. J. 2004, 19, 213-216. [CrossRef]

155. Liu, S.; Fan, G.; Yang, L.; Li, F. Highly efficient transformation of $\Gamma$-valerolactone to valerate esters over structure-controlled copper/zirconia catalysts prepared via a reduction-oxidation route. Appl. Catal. A Gen. 2017, 543, 180-188. [CrossRef]

156. Beaulieu, J.C.; Grimm, C.C. Identification of volatile compounds in cantaloupe at various developmental stages using solid phase microextraction. J. Agric. Food Chem. 2001, 49, 1345-1352. [CrossRef]

157. Selli, S.; Rannou, C.; Prost, C.; Robin, J.; Serot, T. Characterization of aroma-active compounds in rainbow trout (Oncorhynchus mykiss) eliciting an off-odor. J. Agric. Food Chem. 2006, 54, 9496-9502. [CrossRef]

158. Yi, L.; Dong, N.; Liu, S.; Yi, Z.; Zhang, Y. Chemical features of Pericarpium Citri Reticulatae and Pericarpium Citri Reticulatae Viride revealed by GC-MS metabolomics analysis. Food Chem. 2015, 186, 192-199. [CrossRef]

159. Ma, R.; Liu, X.; Tian, H.; Han, B.; Li, Y.; Tang, C.; Zhu, K.; Li, C.; Meng, Y. Odor-active volatile compounds profile of triploid rainbow trout with different marketable sizes. Aquac. Rep. 2020, 17, 100312. [CrossRef]

160. Bryant, R.J.; McClung, A.M. Volatile profiles of aromatic and non-aromatic rice cultivars using SPME/GC-MS. Food Chem. 2011, 124, 501-513. [CrossRef]

161. Dong, S.Y.; Shewfelt, R.L.; Lee, K.S.; Kays, S.J. Comparison of odor-active compounds from six distinctly different rice flavor types. J. Agric. Food Chem. 2008, 56, 2780-2787. [CrossRef]

162. Pino, J.; Marbot, R.; Vázquez, C. Volatile Components of the fruits of vangueria madagascariensis J.F.gmel.from Cuba. J. Essent. Oil Res. 2004, 16, 302-304. [CrossRef]

163. Komes, D.; Ulrich, D.; Lovric, T. Characterization of odor-active compounds in Croatian Rhine Riesling wine, subregion Zagorje. Eur. Food Res. Technol. 2006, 222, 1-7. [CrossRef]

164. Zeng, Y.X.; Zhao, C.X.; Liang, Y.Z.; Yang, H.; Fang, H.Z.; Yi, L.Z.; Zeng, Z. Da Comparative analysis of volatile components from Clematis species growing in China. Anal. Chim. Acta 2007, 595, 328-339. [CrossRef] [PubMed]

165. Takagi, S.; Sato, Y.; Kokubun, A.; Inomata, E.; Agatsuma, Y. Odor-active compounds from the gonads of Mesocentrotus nudus sea urchins fed Saccharina japonica kelp. PLoS ONE 2020, 15, e0231673. [CrossRef] [PubMed]

166. Oliver-Simancas, R.; Muñoz, R.; Díaz-Maroto, M.C.; Pérez-Coello, M.S.; Alañón, M.E. Mango by-products as a natural source of valuable odor-active compounds. J. Sci. Food Agric. 2020, 100, 4688-4695. [CrossRef] [PubMed]

167. Cardeal, Z.L.; Gomes da Silva, M.D.R.; Marriott, P.J. Comprehensive two-dimensional gas chromatography/mass spectrometric analysis of pepper volatiles. Rapid Commun. Mass Spectrom. 2006, 20, 2823-2836. [CrossRef]

168. Pino, J.A.; Quijano, C.E. Estudo de compostos voláteis de ameixa (prunus domestica L. cv. horvin) e estimativa da sua contribuição ao aroma. Cienc. Tecnol. Aliment. 2012, 32, 76-83. [CrossRef]

169. Nezhadali, A.; Shirvan, B.Z. Separation, Identification and Determination of Volatile Compounds of Ziziphora persica Bunge Using HS-SPME/GC-MS. Int. J. Environ. Sci. Dev. 2010, 1, 115-118. [CrossRef]

170. In, H.C.; Soh, M.L.; Se, Y.K.; Choi, H.K.; Kim, K.O.; Kim, Y.S. Differentiation of aroma characteristics of pine-mushrooms (Tricholoma matsutake Sing.) of different grades using gas chromatography-olfactometry and sensory analysis. J. Agric. Food Chem. 2007, 55, 2323-2328. [CrossRef]

171. Engel, E.; Baty, C.; Le Corre, D.; Souchon, I.; Martin, N. Flavor-active compounds potentially implicated in cooked cauliflower acceptance. J. Agric. Food Chem. 2002, 50, 6459-6467. [CrossRef]

172. Purcaro, G.; Tranchida, P.Q.; Jacques, R.A.; Caramão, E.B.; Moret, S.; Conte, L.; Dugo, P.; Dugo, G.; Mondello, L. Characterization of the yerba mate (Ilex paraguariensis) volatile fraction using solid-phase microextraction-comprehensive 2-D GC-MS. J. Sep. Sci. 2009, 32, 3755-3763. [CrossRef] [PubMed]

173. Klesk, K.; Qian, M. Aroma extract dilution analysis of Cv. Marion (Rubus spp. hyb) and Cv. Evergreen (R. laciniatus L.) blackberries. J. Agric. Food Chem. 2003, 51, 3436-3441. [CrossRef] [PubMed]

174. Su, M.S.; Chien, P.J. Aroma impact components of rabbiteye blueberry (Vaccinium ashei) vinegars. Food Chem. 2010, 119, 923-928. [CrossRef]

175. Mardarowicz, M.; Sawicki, R.; Dawidowicz, A.; Wianowska, D. The influence of sample treatment on SPME extracts from conifers. I. Comparison of terpene composition in Engelmann Spruce (Picea engelmanii) using hydrodistillation, SPME and PLE. Ann. Univ. Mariae Curie Sklodowska Sectio AA Chemia 2004, 59, 25-42.

176. Aznar, M.; López, R.; Cacho, J.F.; Ferreira, V. Identification and quantification of impact odorants of aged red wines from Rioja, GC-olfactometry, quantitative GC-MS, and odor evaluation of HPLC fractions. J. Agric. Food Chem. 2001, 49, 2924-2929. [CrossRef]

177. Cu, J.Q.; Perineau, F.; Gaset, A. Volatile components of violet leaves. Phytochemistry 1992, 31, 571-573. [CrossRef]

178. Sheibani, E.; Duncan, S.E.; Kuhn, D.D.; Dietrich, A.M.; Newkirk, J.J.; O'Keefe, S.F. Changes in flavor volatile composition of oolong tea after panning during tea processing. Food Sci. Nutr. 2016, 4, 456-468. [CrossRef]

179. Reale, S.; Pace, L.; D’Archivio, A.A.; De Angelis, F.; Marcozzi, G. Volatiles fingerprint of Artemisia umbelliformis subsp. eriantha by headspace-solid phase microextraction GC-MS. Nat. Prod. Res. 2014, 28, 61-66. [CrossRef] [PubMed]

180. Verzera, A.; Trozzi, A.; Cotroneo, A.; Lorenzo, D.; Dellacassa, E. Uruguayan essential oil. 12. Composition of Nova and Satsuma mandarin oils. J. Agric. Food Chem. 2000, 48, 2903-2909. [CrossRef]

181. Salido, S.; Altarejos, J.; Nogueras, M.; Saánchez, A.; Luque, P. Chemical composition and seasonal variations of rosemary oil from southern Spain. J. Essent. Oil Res. 2011, 15, 10-14. [CrossRef] 
182. Shalit, M.; Katzir, N.; Tadmor, Y.; Larkov, O.; Burger, Y.; Shalekhet, F.; Lastochkin, E.; Ravid, U.; Amar, O.; Edelstein, M.; et al. Acetyl-CoA: Alcohol acetyltransferase activity and aroma formation in ripening melon fruits. J. Agric. Food Chem. 2001, 49, 794-799. [CrossRef] [PubMed]

183. Pino, J.A.; Queris, O. Characterization of odor-active compounds in guava wine. J. Agric. Food Chem. 2011, 59, 4885-4890. [CrossRef] [PubMed]

184. Benzo, M.; Gilardoni, G.; Gandini, C.; Caccialanza, G.; Finzi, P.V.; Vidari, G.; Abdo, S.; Layedra, P. Determination of the threshold odor concentration of main odorants in essential oils using gas chromatography-olfactometry incremental dilution technique. J. Chromatogr. A 2007, 1150, 131-135. [CrossRef]

185. Pino, J.A.; Rosado, A.; Goire, I.; Roncal, E. Evaluation of Flavor Characteristic Compounds in Dill Herb Essential Oil by Sensory Analysis and Gas Chromatography. J. Agric. Food Chem. 1995, 43, 1307-1309. [CrossRef]

186. Džamić, A.M.; Soković, M.D.; Ristić, M.S.; Novaković, M.; Grujić-Jovanović, S.; Tešević, V.; Marin, P.D. Antifungal and antioxidant activity of Mentha longifolia (L.) Hudson (Lamiaceae) essential oil. Bot. Serbica 2010, 34, 57-61.

187. Saroglou, V.; Dorizas, N.; Kypriotakis, Z.; Skaltsa, H.D. Analysis of the essential oil composition of eight Anthemis species from Greece. J. Chromatogr. A 2006, 1104, 313-322. [CrossRef]

188. Loskutov, A.V.; Beninger, C.W.; Hosfield, G.L.; Sink, K.C. Development of an improved procedure for extraction and quantitation of safranal in stigmas of Crocus sativus L. using high performance liquid chromatography. Food Chem. 2000, 69, 87-95. [CrossRef]

189. Guo, X.; Ho, C.T.; Wan, X.; Zhu, H.; Liu, Q.; Wen, Z. Changes of volatile compounds and odor profiles in Wuyi rock tea during processing. Food Chem. 2021, 341, 128230. [CrossRef]

190. Denk, P.; Ortner, E.; Buettner, A. Characterization of odorants in waxes for hot melt adhesives using sensory and instrumental analyses. Int. J. Adhes. Adhes. 2019, 95, 102406. [CrossRef]

191. Kaneko, S.; Chen, J.; Wu, J.; Suzuki, Y.; Ma, L.; Kumazawa, K. Potent Odorants of Characteristic Floral/Sweet Odor in Chinese Chrysanthemum Flower Tea Infusion. J. Agric. Food Chem. 2017, 65, 10058-10063. [CrossRef] [PubMed]

192. Murakami, S.; Li, W.; Matsuura, M.; Satou, T.; Hayashi, S.; Koike, K. Composition and seasonal variation of essential oil in Alpinia zerumbet from Okinawa Island. J. Nat. Med. 2009, 63, 204-208. [CrossRef] [PubMed]

193. Zhang, K.; Lin, T.F.; Zhang, T.; Li, C.; Gao, N. Characterization of typical taste and odor compounds formed by Microcystis aeruginosa. J. Environ. Sci. 2013, 25, 1539-1548. [CrossRef]

194. Mockute, D.; Bernotiene, G. The main citral-geraniol and carvacrol chemotypes of the essential oil of Thymus pulegioides L. growing wild in Vilnius district (Lithuania). J. Agric. Food Chem. 1999, 47, 3787-3790. [CrossRef]

195. Bylaite, E.; Meyer, A.S. Characterisation of volatile aroma compounds of orange juices by three dynamic and static headspace gas chromatography techniques. Eur. Food Res. Technol. 2006, 222, 176-184. [CrossRef]

196. Petrović, G.M.; Stamenković, J.G.; Stojanović, G.S.; Mitić, V.D.; Zlatković, B.K. Chemical Profile of Essential Oils and Headspace Volatiles of Chaerophyllum hirsutum from Serbia. Nat. Prod. Commun. 2017, 12, 1934578X1701200. [CrossRef]

197. Isidorov, V.A.; Krajewska, U.; Dubis, E.N.; Jdanova, M.A. Partition coefficients of alkyl aromatic hydrocarbons and esters in a hexane-acetonitrile system. J. Chromatogr. A 2001, 923, 127-136. [CrossRef]

198. Jiang, Y.; Zhao, L.; Yuan, M.; Fu, A. Identification and changes of different volatile compounds in meat of crucian carp under short-term starvation by GC-MS coupled with HS-SPME. J. Food Biochem. 2017, 41, e12375. [CrossRef]

199. Wu, S.; Zorn, H.; Krings, U.; Berger, R.G. Volatiles from submerged and surface-cultured beefsteak fungus, Fistulina hepatica. Flavour Fragr. J. 2007, 22, 53-60. [CrossRef]

200. Ishola, F.T.; Aboaba, S.A.; Choudhary, M.I.; Ekundayo, O. Chemical and Biological Assessments of the Essential Oils of Chrysophyllum albidum G. Don. J. Agric. Sci. Technol. A 2017, 7, 234-245. [CrossRef]

201. Eri, S.; Khoo, B.K.; Lech, J.; Hartman, T.G. Direct thermal desorption-gas chromatography and gas chromatography-mass spectrometry profiling of hop (Humulus lupulus L.) Essential oils in support of varietal characterization. J. Agric. Food Chem. 2000, 48, 1140-1149. [CrossRef]

202. Zhang, X.-X.; Sun, J.-Y.; Niu, L.-X.; Zhang, Y.-L. Chemical Compositions and Antioxidant Activities of Essential Oils Extracted from the Petals of Three Wild Tree Peony Species and Eleven Cultivars. Chem. Biodivers. 2017, 14, e1700282. [CrossRef]

203. Baek, Y.S.; Park, P.H.; Kim, S.Y.; An, H.R.; Park, P.M.; Chio, O.; Kwon, O.K.; Son, I.C. Analysis of Floral Scent in Cymbidium Cultivar 'Sunny Bell' by Electronic Nose and Gas Chromatography-Mass Spectrometry. 2014. Available online: https://ashs. confex.com/ashs/2016/webprogram/Paper23542.html (accessed on 17 July 2021).

204. Sartin, J.H.; Halsall, C.J.; Davison, B.; Owen, S.; Hewitt, C.N. Determination of biogenic volatile organic compounds (C8-C16) in the coastal atmosphere at Mace Head, Ireland. Anal. Chim. Acta 2001, 428, 61-72. [CrossRef]

205. da Silva Oliveira, M.; Monsalve, J.O.; Nerin, C.; Padula, M.; Godoy, H.T. Characterization of odorants from baby bottles by headspace solid phase microextraction coupled to gas chromatography-olfactometry-mass spectrometry. Talanta 2020, $207,120301$. [CrossRef]

206. Idris, O.; Wintola, O.; Afolayan, A. Comparison of the Proximate Composition, Vitamins (Ascorbic Acid, $\alpha$-Tocopherol and Retinol), Anti-Nutrients (Phytate and Oxalate) and the GC-MS Analysis of the Essential Oil of the Root and Leaf of Rumex crispus L. Plants 2019, 8, 51. [CrossRef]

207. Park, H.-J.; Lee, S.; Song, S.; Kim, Y.-S. Characterization of Volatile Components in Makgeolli, a Traditional Korean Rice Wine, with or without Pasteurization, During Storage. Molecules 2013, 18, 5317-5325. [CrossRef] [PubMed] 
208. Joshi, R.K. Chemical constituents and antibacterial property of the essential oil of the roots of Cyathocline purpurea. J. Ethnopharmacol. 2013, 145, 621-625. [CrossRef] [PubMed]

209. Schreiner, L.; Bauer, J.; Ortner, E.; Buettner, A. Structure-Odor Activity Studies on Derivatives of Aromatic and Oxygenated Monoterpenoids Synthesized by Modifying p-Cymene. J. Nat. Prod. 2020, 83, 834-842. [CrossRef] [PubMed]

210. Zafeiropoulou, V.; Tomou, E.M.; Douros, A.; Skaltsa, H. The Effect of Successive Harvesting on The Volatile Constituents of Two Essential Oils of Cultivated Populations of Sea Fennel (Crithmum maritimum L.) in Greece. J. Essent. Oil-Bear. Plants 2021, $24,1-11$. [CrossRef]

211. Youssef, F.S.; Mamatkhanova, M.A.; Mamadalieva, N.Z.; Zengin, G.; Aripova, S.F.; Alshammari, E.; Ashour, M.L. Chemical Profiling and Discrimination of Essential Oils from Six Ferula Species Using GC Analyses Coupled with Chemometrics and Evaluation of Their Antioxidant and Enzyme Inhibitory Potential. Antibiotics 2020, 9, 518. [CrossRef] [PubMed]

212. Faizal, A.; Azar, A.W.P.; Turjaman, M.; Esyanti, R.R. Fusarium solani induces the formation of agarwood in Gyrinops versteegii (Gilg.) Domke branches. Symbiosis 2020, 81, 15-23. [CrossRef]

213. Passos, X.S.; Castro, A.C.M.; Pires, J.S.; Garcia, A.C.F.; Campos, F.C.; Fernandes, O.F.L.; Paula, J.R.; Ferreira, H.D.; Santos, S.C.; Ferri, P.H.; et al. Composition and antifungal activity of the essential oils of Caryocar brasiliensis. Pharm. Biol. 2003, 41, 319-324. [CrossRef]

214. Saftner, R.; Luo, Y.; McEvoy, J.; Abbott, J.A.; Vinyard, B. Quality characteristics of fresh-cut watermelon slices from non-treated and 1-methylcyclopropene- and/or ethylene-treated whole fruit. Postharvest Biol. Technol. 2007, 44, 71-79. [CrossRef]

215. Li, Q.; Li, Y.; Luo, Y.; Xiao, L.; Wang, K.; Huang, J.; Liu, Z. Characterization of the key aroma compounds and microorganisms during the manufacturing process of Fu brick tea. LWT 2020, 127, 109355. [CrossRef]

216. Sharma, R.K.; Kaur, H.; Singh, M.; Kumar, M.; Sharma, R.; Shah, G.C.; Sharma, P. Chemical Composition and Antimicrobial Properties of Essential Oil Anaphalis triplinervis from Western Himalaya. Chem. Nat. Compd. 2019, 55, 751-753. [CrossRef]

217. Zhai, X.; Granvogl, M. Key Odor-Active Compounds in Raw Green and Red Toona sinensis (A. Juss.) Roem. And Their Changes during Blanching. J. Agric. Food Chem. 2020, 68, 7169-7183. [CrossRef] [PubMed]

218. Zhao, J.; Guo, Y.; Suo, X.; Yuan, J. Effect of dietary zinc level on serum carotenoid levels, body and shank pigmentation of chickens after experimental infection with coccidia. Arch. Anim. Nutr. 2006, 60, 218-228. [CrossRef]

219. Zanan, R.; Khandagale, K.; Hinge, V.; Elangovan, M.; Henry, R.J.; Nadaf, A. Characterization of fragrance in sorghum (Sorghum bicolor (L.) Moench) grain and development of a gene-based marker for selection in breeding. Mol. Breed. 2016, 36, 146. [CrossRef]

220. Lv, S.D.; Wu, Y.S.; Song, Y.Z.; Zhou, J.S.; Lian, M.; Wang, C.; Liu, L.; Meng, Q.X. Multivariate Analysis Based on GC-MS Fingerprint and Volatile Composition for the Quality Evaluation of Pu-Erh Green Tea. Food Anal. Methods 2015, 8, 321-333. [CrossRef]

221. Zhang, W.-J.; Liu, C.; Yang, R.-J.; Zheng, T.-T.; Zhao, M.-M.; Ma, L.; Yan, L. Comparison of volatile profiles and bioactive components of sun-dried Pu-erh tea leaves from ancient tea plants on Bulang Mountain measured by GC-MS and HPLC. J. Zhejiang Univ. Sci. B 2019, 20, 563-575. [CrossRef] [PubMed]

222. Flamini, G.; Tebano, M.; Cioni, P.L. Volatiles emission patterns of different plant organs and pollen of Citrus limon. Anal. Chim. Acta 2007, 589, 120-124. [CrossRef] [PubMed] 